\title{
A review of the inferred geodynamic evolution of the Dharwar craton over the ca. $3.5-2.5$ Ga period, and possible implications for global tectonics ${ }^{1}$
}

\author{
P.V. Sunder Raju, P.G. Eriksson, O. Catuneanu, S. Sarkar, and S. Banerjee
}

P.V. Sunder Raju. National Geophysical Research Institute (CSIR), Uppal Road, Hyderabad, Andhra Pradesh, India. P.G. Eriksson. Department of Geology, University of Pretoria, Pretoria 0002, South Africa.

O. Catuneanu. Department of Earth and Atmospheric Sciences, 1-26 Earth Sciences Building, University of Alberta, Edmonton, AB T6G 2E3, Canada. S. Sarkar. Department of Geological Sciences, Jadavpur University, Kolkata 700 032, India.

S. Banerjee. Department of Earth Sciences, IIT Bombay, Pawai, Mumbai 400 076, India.

\begin{abstract}
The geological history and evolution of the Dharwar craton from ca. 3.5-2.5 Ga is reviewed and briefly compared with a second craton, Kaapvaal, to allow some speculation on the nature of global tectonic regimes in this period. The Dharwar craton is divided into western (WDC) and eastern (EDC) parts (separated possibly by the Closepet Granite Batholith), based on lithologi-cal differences and inferred metamorphic and magmatic genetic events. A tentative evolution of the WDC encompasses an early, ca. 3.5 Ga protocrust possibly forming the basement to the ca. 3.35-3.2 Ga Sargur Group greenstone belts. The latter are interpreted as having formed through accretion of plume-related ocean plateaux. The approximately coeval Peninsular Gneiss Complex (PGC) was possibly sourced from beneath plateau remnants, and resulted in high-grade metamorphism of Sargur Group belts at ca. 3.13-2.96 Ga. At about 2.9-2.6 Ga, the Dharwar Supergroup formed, comprising lower Bababudan (largely braided fluvial and subaerial volcanic deposits) and upper Chitradurga (marine mixed clastic and chemical sedimentary rocks and subaqueous volcanics) groups. This supergroup is preserved in younger greenstone belts with two distinct magmatic events, at 2.7-2.6 and 2.58-2.54 Ga, the latter approximately coincident with ca. 2.6-2.5 Ga granitic magmatism which essentially completed cratonization in the WDC. The EDC comprises 2.7-2.55 Ga tonalite-trondhjemitegranodiorite (TTG) gneisses and migmatites, approximately coeval greenstone belts (dominated by volcanic lithologies), with minor inferred remnants of ca. 3.38-3.0 Ga crust, and voluminous 2.56-2.5 Ga granitoid intrusions (including the Closepet Batholith). An east-to-west accretion of EDC island arcs (or of an assembled arc - granitic terrane) onto the WDC is debated, with a postulate that the Closepet Granite accreted earlier onto the WDC as part of a "central Dharwar" terrane. A final voluminous granitic cratonization event is envisaged to have affected the entire, assembled Dharwar craton at ca. 2.5 Ga. When Dharwar evolution is compared with that of Kaapvaal, while possibly global magmatic events and freeboard-eustatic changes at ca. 2.7$2.5 \mathrm{Ga}$ may be identified on both, the much earlier cratonization (by ca. $3.1 \mathrm{Ga}$ ) of Kaapvaal contrasts strongly with the ca. $2.5 \mathrm{Ga}$ stabilization of Dharwar. From comparing only two cratons, it appears that genetic and chronologic relationships between mantle thermal and plate tectonic processes were complex on the Archaean Earth. The sizes of the Kaapvaal and Dharwar cratons might have been too limited yet to support effective thermal blanketing and thus accommodate Wilson Cycle onset. However, tectonically driven accretion and amalgamation appear to have predominated on both evolving cratons.
\end{abstract}

\begin{abstract}
Résumé : L'histoire géologique et l'évolution du craton de Dharwar ( 3,5-2,5 Ga) sont examinées et sommairement comparées a`celles d'un second craton, celui de Kaapvaal, afin de permettre une certaine spéculation sur la nature des régimes tectoniques globaux durant cette période. Le craton de Dharwar est divisé entre une partie ouest (WDC) et une partie est (EDC), lesquelles sont possiblement séparées par le batholite granitique de Closepet. La division est basée sur les différences lithologiques et des événements génétiques métamorphiques et magmatiques inférés. Une évolution tentative du WDC comprend une protocroûte précoce, $\sim 3,5 \mathrm{Ga}$, formant possiblement le socle des ceintures vertes du Groupe de Sargur, 3,35-3,2 Ga. Ces dernières se seraient formées par l'accrétion de plateaux océaniques reliés `a des panaches. Le complexe gneissique presque contemporain de Peninsular provient possiblement de vestiges sous les plateaux et a conduit au métamorphisme élevé des ceintures du Groupe de Sargur, il y a environ 3,13-2,96 Ga. Vers 2,9-2,6 Ga, le supergroupe de Dharwar s'est formé; il comprend le groupe de Bababudan inférieur (principalement des dépôts fluviaux anastomosés et des dépôts volcaniques subaérien et le groupe de Chitradurga supérieur (un mélange de roches sédimentaires marines clastiques et chimiques et des roches volcaniques subaquatiques). Ce supergroupe est préservé dans des ceintures de roches volcaniques plus jeunes, il témoigne de deux activités magmatiques distinctes, `a 2,7-2,6 Ga et `a 2,58-2,54 Ga, cette dernière activité coïncidant approximativement avec le magmatisme granitique $\sim 2,6-2,5$ Ga qui a essentiellement complété la cratonisation dans le WDC. La partie est du craton de Dharwar comprend des gneiss TTG (tonalite-trondhjémite-granodiorite) de 2,7-2,55 Ga et des migmatites, des ceintures de roches vertes approximativement contemporaines (dominées par des lithologies volcaniques), avec des restes mineurs d'une croûte
\end{abstract}

Corresponding author: P.V. Sunder Raju (e-mail: perumala.raju@gmail.com; pvsraju@eos.ubc.ca).

${ }^{1}$ This article is one of a selection of papers published in this special issue in honour of John Tuzo Wilson, a man who moved mountains, and his contributions to earth sciences. 


\begin{abstract}
3,38-3,0 Ga inférée et de volumineuses intrusions granitoïdes (incluant le batholite de Closepet) 2,56-2,5 Ga. L'accrétion de l'est vers l'ouest d'arcs insulaires du EDC (ou d'un terrane d'arc granitique assemblé) au WDC est discutée, mais il est concevable que le granite de Closepet ait été accrété plus tôt au WDC en tant que partie d'un terrane «Dharwar central ». Un événement final de volumineuse cratonisation granitique aurait affecté, vers 2,5 Ga, tout le craton de Dharwar assemblé. Bien que des événements magmatiques globaux et des changements eustatiques de dégagement vers 2,7-2,5 Ga puissent être identifiés sur les deux cratons, lorsque l'évolution du Dharwar est comparée à celle du Kaapvall, la cratonisation beaucoup plus précoce (vers 3,1 Ga) du Kaapvall contraste fortement avec la stabilisation du Dharwar vers 2,5 Ga. En comparant seulement deux cratons, il semble qu'à l'Archéen les relations génétiques et chronologiques entre les processus thermiques du manteau et la tectonique des plaques étaient complexes sur la Terre. Les tailles des cratons de Kaapvall et de Dharwar pouvaient avoir été trop limitées pour déjà soutenir un isolement thermique efficace et ainsi permettre le début d'un cycle de Wilson. Toutefois, l'accrétion poussée par la tectonique et l'amalgamation semblent avoir prédominé sur les deux cratons en évolution. [Traduit par la Rédaction]
\end{abstract}

\section{Introduction}

The importance of Wilson's work in global geodynamics

John Tuzo Wilson is renowned for introducing the hotspot concept and transform faults to the plate tectonic paradigm, and also for the concept of ocean opening and closure now encapsulated in the well-known Wilson Cycle (Wilson 1965, 1966). The Wilson Cycle can be seen as an integral part of the larger concept of the supercontinent cycle. When supercontinental dynamics are traced back into the deep geological past, as for the Proterozoic or even possibly the Archaean, it is clear that the relatively simple scenario of rifting of a large continental mass, separation of the relatively large daughter fragments on either side of a growing ocean, and eventual ocean closure together with reassembly of the earlier rifted margins in approximately similar mutual relationship (as implicit in Wilson's 1966 cycle derived from the Atlantic ocean example), becomes much more complex (e.g., Bleeker 2003; Eriksson et al. 2011a, 2011b). Proterozoic supercontinents fragmented into many daughter components, and reassembly of the subsequent supercontinent several hundred million years later, encompassed a reassembly of fragments in a plethora of new relative orientations, reflecting multiple rotations and complex plate movements within a veritably Byzantine amalgamation history (e.g., Hartnady 1986; Hoffman 1991; Dalziel 1991; Moores 1991).

\section{Supercontinents, supercratons, and the} supercontinent cycle

The term "supercontinent" is used with many different meanings, particularly regarding size, and further complexity is introduced with the term "supercraton". Bleeker (2003) discusses a Late Archaean geodynamic scenario wherein he evaluates three possible end-member models: (1) a single supercontinent (viz. the "Kenorland solution" based on the work of Williams et al. 1991) scenario; (2) a limited set of supercratons (e.g., Vaalbara, Superia, Sclavia) which can be equated with smaller landmasses than that implicit in the single supercontinent model; and (3) many much smaller supercratons. The Dharwar craton might be considered as such a smaller supercraton, composed of the Eastern and Western Dharwar cratons. Williams et al. (1991) postulated Kenorland as comprising the current North American cratons, while a number of subsequent workers would see the Kenorland supercontinent as being made up essentially of these plus the Baltica and Siberian cratons (e.g., Aspler and Chiarenzelli 1998). A relatively small amalgamation such as Vaalbara (Kaapvaal-Pilbara cratons; e.g., Cheney 1996) or Dharwar is dwarfed in size by both original and expanded Kenorland reconstructions, thereby possibly questioning the appellation of "supercraton" applied by Bleeker (2003), o r more recently, by Smirnov et al. (2013).

While the supercontinent cycle is widely accepted as a fundamental concept in geology, and is generally seen as one of the major controls on Earth's geological, palaeoclimatic, and biological evolution (e.g., Rogers and Santosh 2002), its antiquity, plates making up a specific supercontinent, and genesis (including relationship with mantle convective and plume processes) have gen- erated much more debate (e.g., Unrug 1992; Rogers 1996; Dalziel 1997; Condie et al. 2001; Meert 2002; Bleeker 2003; Personen et al. 2003; Condie 2004a, 2004b; Eriksson et al. 2004, 2009, 2011a; Zhong et al. 2007; Hou et al. 2008; Nelson 2008). Supercontinents extended to at least $2 \mathrm{Ga}$ (Miall 1997) and most likely to the Neoarchaean (e.g., Aspler and Chiarenzelli 1998). Amongst a large number of postulated ancient supercontinents and configurations thereof (e.g., Rogers and Santosh 2002) are a ca. 3.0 Ga "Ur" (Rogers 1996; comprising Kalahari (assembled KaapvaalZimbabwe cratons), Western Dronning Maud, the Dharwar, Bhandara, and Singhbhum cratons of India, the Napier and Pilbara cratons) and one or possibly two Neoarchaean supercontinents, "Kenor-land" (assembly of North American cratonic blocks, Baltic and Siberian shields) and a "southern" equivalent (Button 1976; Piper 1983; Gaál 1992; Stanistreet 1993; Cheney 1996; Aspler and Chiarenzelli 1998). The latter is proposed to have encompassed the Zimbabwe, Kaapvaal, Pilbara, São Francisco, and cratons from present-day India (Aspler and Chiarenzelli 1998).

Dharwar and Kaapvaal cratons

In both "Ur" and the "southern" (modern geographical context) Neoarchaean supercontinents, the Kaapvaal craton of southern Africa and the Dharwar craton of India are included in a common configuration. Recently also, a comparison of the geological evolution of the Singhbhum (India) and Kaapvaal cratons was made (Mazumder et al. 2012) which argued against any amalgamation of these cratons in the Palaeoproterozoic. Eriksson et al. (2009, 2011a) examined the supercontinental affinities of the Kaapvaal craton more generally, including possible assembly with Dharwar; they argued against the latter assembly, citing several reasons such as poor age data from the Indian terrane.

Kaapvaal is more often seen as forming part of the "Vaalbara" assembly with the Pilbara craton of Australia. This assembly was first suggested by Button (1976) and discussed in more detail by Cheney (1996) who also added the Zimbabwe craton and possibly Grunehogna (Antarctica) as well. Palaeomagnetic work by Wingate (1998) and Strik et al. (2007) appeared to discount a Kaapvaal amalgamation with Pilbara for the period of the WitwatersrandTransvaal successions of Kaapvaal (ca. 3.1-2.05 Ga), as did detailed comparative chronology over the 3650-2200 Ma period for both cratons by Nelson (2008). In contrast, recent palaeomagnetic studies by de Kock et al. (2009) validate the Vaalbara concept, and the work of Smirnov et al. (2013) provides evidence for definite exclusion of Zimbabwe from the greater Vaalbara terrane, while also supporting a separate Zimbabwe-Yilgarn craton assembly; the use of precise chronology and accurate palaeomagnetic determinations related to dyke swarms forms the basis of many of these recent studies (e.g., Ernst et al. 2005; Bleeker and Ernst 2006; Kumar et al. 2012). While such methods strongly support a combined Kaapvaal-Pilbara cratonic terrane, the noted differences in geochronological profiles of both cratons (Kaapvaal and Pilbara), in details of supercratonic cover sequences, and an apparent lack of suitable mobile belts of the right ages, appear to be in contrast to their inferred assembly. However, it can be argued that the 
similarities in cover sequence stratigraphies over the ca. 35602000 Ma period appear to outweigh these differences, and cratonmarginal mobile belts would inherently have been poorly preserved over a long geodynamic history of this antiquity.

However, the nature of early Precambrian tectonic regimes and processes that might have been responsible for any KaapvaalPilbara shared event history, at this stage, must remain speculative. The Dharwar craton, in contrast, has deformed supracrustal successions of great antiquity as well as inferred mobile belts and reflects a different apparent tectonic history and process of craton amalgamation (Eastern and Western Dharwar cratons). Recently acquired age data from the Dharwar craton enable a much more detailed geodynamic interpretation, and we will briefly also com-pare this with Kaapvaal. This paper thus aims to review the geo-logical evolution of the Dharwar craton from ca. 3.5-2.5 Ga, and will attempt to interpret commonalities and distinctions arising with Kaapvaal geodynamic history as a subordinate aim. The geo-dynamic evolution of Kaapvaal has been summarized in a number of recent papers (e.g., Eriksson et al. 2006a, 2006b, 2011a; Bumby et al. 2012; Mazumder et al. 2012; Eriksson and Condie 2013) and is thus not repeated here except for a summary figure (Fig. 2). The comparisons made with Kaapvaal enable comments on Neoarchaean-Palaeoproterozoic tectonic regimes to be made, in the spirit of the theme of this special issue in honour of the seminal work of John Tuzo Wilson.

\section{Geology of the Dharwar craton}

The Indian shield is divided into three main proto-continents: Bundelkhand, Aravalli, and Dharwar-Singhbhum (Naqvi et al. 1974; Radhakrishna and Naqvi 1986). The Karnataka and Singhbhum nuclei (KN and $\mathrm{SN}$ ) of the Dharwar-Singhbhum protocontinent are made up of rocks older than $2.5 \mathrm{Ga}$, and this Archaean continental crust of the South Indian shield has been investigated intensely since the pioneering work of Foote (1886).

The well-studied Dharwar craton forms a major portion of the Dharwar-Singhbhum proto-continent and represents an advanced stage of cratonization characterized by complex tectonic and structural controls (Naqvi 1981; Swami Nath and Ramakrishnan 1981; Divakar Rao and Rama Rao 1982; Naqvi and Rogers 1983, 1987; Radhakrishna 1983, 1984; Pichamuthu and Srinivasan 1984; Radhakrishna and Naqvi 1986; Rogers 1986; Chadwick et al. 1988; Chardon et al. 1988; Naha et al. 1990). The Dharwar craton (DC) occurs to the south of the Narmada and Godavari Lineament, and is bounded by Arabian Sea to the west and the Middle Proterozoic Mobile Belt (MPMB) to the east and south (Fig. 1). The differences in regional facies in terms of lithology, volcano-sedimentary environment, metamorphism, and magmatism suggest a possible division of the DC into a Western and an Eastern Dharwar craton separated possibly by the Closepet Granite (Vishwanatha and Ramakrishnan 1976; Swami Nath and Ramakrishnan 1981; Naqvi and Rogers 1987). However, Chadwick et al. (1996) suggested a major mylonitic ductile shear zone ( $\sim 400 \mathrm{~km}$ long), separating the eastern (high-temperature metamorphic terrain) and western blocks (low-temperature metamorphic terrain). This shear zone between the Western Dharwar (WDC) and Eastern Dharwar (EDC) cratons is characterized by a gravity gradient of $4 \mathrm{G} \mathrm{Gal}\left(1 \mathrm{Gal}=1 \mathrm{~cm} / \mathrm{s}^{2}\right)$, which extends from the west of Bangalore along the eastern margin of the Chitradurga Schist belt up to the west coast of India (Naqvi 1973). The WDC is synonymous with the Karnataka nucleus (and coincidently also, spatially, with the geographic entity, the state of Karnataka, India), which is an ellipticalshaped area to the west of the outcrops of the Closepet Granite, with K-rich granite plutons on at least two sides (Radhakrishna and Naqvi 1986). The KN is overlain by the Deccan basalts on its northern margin and in the west is terminated at a passive continental margin (Arabian Sea) developed at the time of Gondwana breakup; to the south, it is transitional into granulite facies assemblages developed at ca. 2600-2700 Ma (Venkatasubramanian and Narayanaswamy 1974), while the eastern margin is poorly defined (Fig. 1).

\section{Western Dharwar craton (WDC)}

The Western Dharwar craton contains three suites of approximately north-south-oriented schist belts: the oldest, the Sargur Group (Radhakrishna 1967; Viswanatha and Ramakrishnan 1976), the Peninsular Gneissic Complex (PGC), and the youngest, the Dharwar Supergroup (Ramakrishnan and Swaminatha 1976; Swami Nath et al. 1976; Viswanatha and Ramakrishnan 1976; Radhakrishna and Naqvi 1986) ( Table 1). Generally, the younger schist or greenstone belts in the northern region are less metamorphosed than those in the southern part (Naqvi et al. 1988). Metamorphism is regional, affecting all parts of the craton (Radhakrishna 1983). The principal structural trend in the WDC is approximately northwest-southeast to north-south as shown by major shear zones and the elongation of the various schist belts. Rock suites of different ages exhibit a similar sequence of deformation (Naha et al. 1986). Detailed structural studies of the WDC spanning over three decades have established a correlatable sequence of superposed folding events in all schist belts (low as well as high grade), the PGC, and banded granulites (Naqvi 1973; Roy and Biswas 1979; Chadwick et al. 1981a, 1981b; Ghosh and Sengupta 1985; Mukhopadyay 1986; Naha et al. 1986, 1991).

North-south change in metamorphic facies has been demonstrated in the coherent schist or greenstone belts which tend to interfinger with the more widespread PGC; relations of the greenstone belts to the PGC remain contentious (e.g., Radhakrishna and Ramakrishnan 1990), and Naqvi (1981) suggested the interfinger-ing between PGC and greenstones developed over a ca. 1 gigayear time period. The Closepet Granite and its equivalents occur primarily in the eastern part of the Dharwar craton. Small bodies of diapiric rock with high concentrations of K-feldspar and quartz are present in the Western Dharwar craton. The southern part of the Western Dharwar craton contains a number of metamor-phosed ultramafic bodies, many of which form layered intrusive complexes. Ultramafic volcanic rocks often exhibit relict spinifex texture and pillow structures. Geobarometers suggest 5-6 kbar $(1 \mathrm{kbar}=100$ $\mathrm{MPa}$ ) for the gneiss-granulite transition zone at the southern edge of the Western Dharwar craton (Janardhan and Srikantappa 1975). Part of the Proterozoic Kaladgi basin overlaps with the Western Dharwar craton.

Greenstone belts in the southern part of the craton tend to be small, engulfed in gneisses, metamorphosed to amphibolite facies and are older (Radhakrishna 1967; Viswanatha and Ramakrishnan 1976) than those in the northern lower grade belts (Swami Nath and Ramakrishnan 1981). In addition to the widespread PGC, thus, there are the Sargur Group supracrustal enclaves, as well as the southern and northern type greenstone belts. While there has been much debate on the topic (e.g., Radhakrishna and Ramakrishnan 1990), the southern greenstone belts (smaller, higher grade) appear to be essentially equivalent to the older Sargur Group enclaves, and the north-ern greenstone belts equate essentially to the younger Dharwar Supergroup (see discussion and references in Ramakrishnan and Vaidyanadhan 2008). Many of the conclusions drawn remain highly controversial. Some workers have documented evidence supporting a structural episode prior to the deposition of the Bababudan Group, the lower unit of the Dharwar Supergroup (Naqvi 1985; Radhakrishna and Naqvi 1986; Naqvi and Rogers 1987). They studied the Talya conglomerate of the Chitradurga Schist belt and observed bent lineation in quartzite pebbles, folding and fracturing parallel to the main Dharwar direction in banded iron formations (BIFs) to infer a deformation and metamorphism event before the deposition of the Dharwar Supergroup (Naqvi and Hussain 1973). This pre-Dharwar event is thought to reflect part of the geodynamic controls on the Sargur Group.

The Sargur Group is $>3000$ Ma and comprises gneisses and enclaves in the gneisses and associated granulites (Janardhan et al. 
Fig. 1. Geological sketch map of the Dharwar craton showing the greenstone belts and plutons (after Geological Survey of India 2006 and Chardon et al. 2008). EDC, Eastern Dharwar; WDC, Western Dharwar; SMDC, southern margin of Dharwar craton.

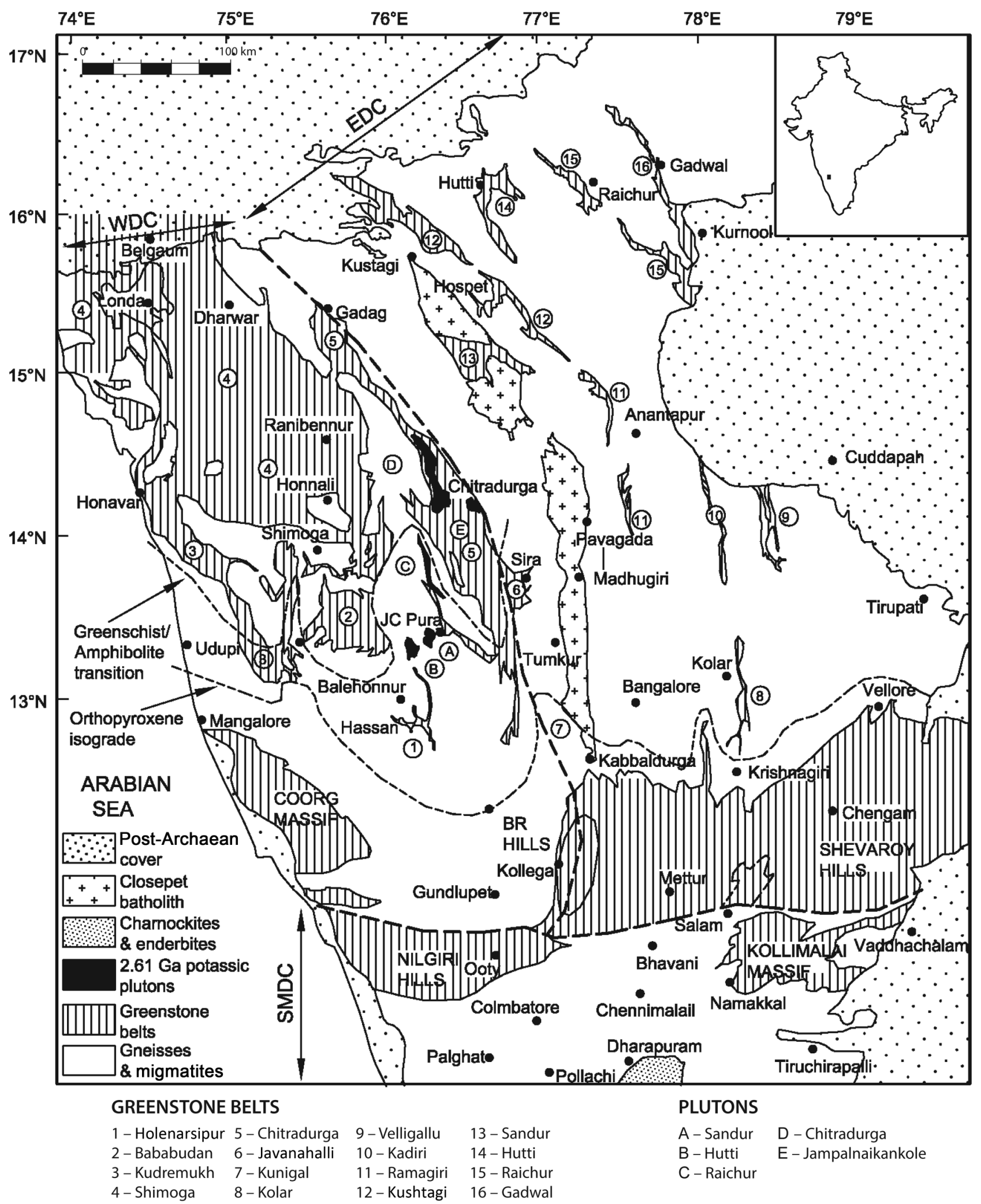

1986). Bhaskara Rao et al. (1983) and Monrad (1983) have dated the gneisses in the vicinity of the Holenarsipur schist belt. The gneisses to the east of the belt have given a Rb-Sr age of $3000 \pm$ $10 \mathrm{Ma}\left({ }^{87} \mathrm{Sr} /{ }^{86} \mathrm{Sr}=0.70323 \pm 0.00035\right)$ The gneisses (Halekote trond- hjemites) to the north of the belt are 3070 Ma old, which is presumed to be a metamorphic age. Some of the cordierite gneisses of southern Karnataka broadly falling within the zone of the Closepet Granite have given an $\mathrm{Rb}-\mathrm{Sr}$ age of $3010 \pm 90 \mathrm{Ma}$ 
Fig. 2. Evolution of Kaapvaal (KV) Precambrian supracrustal rocks (after Eriksson et al. 2006a). BIF, banded iron formation; HF, high freeboard.

\section{KAAPVAAL CRATON}

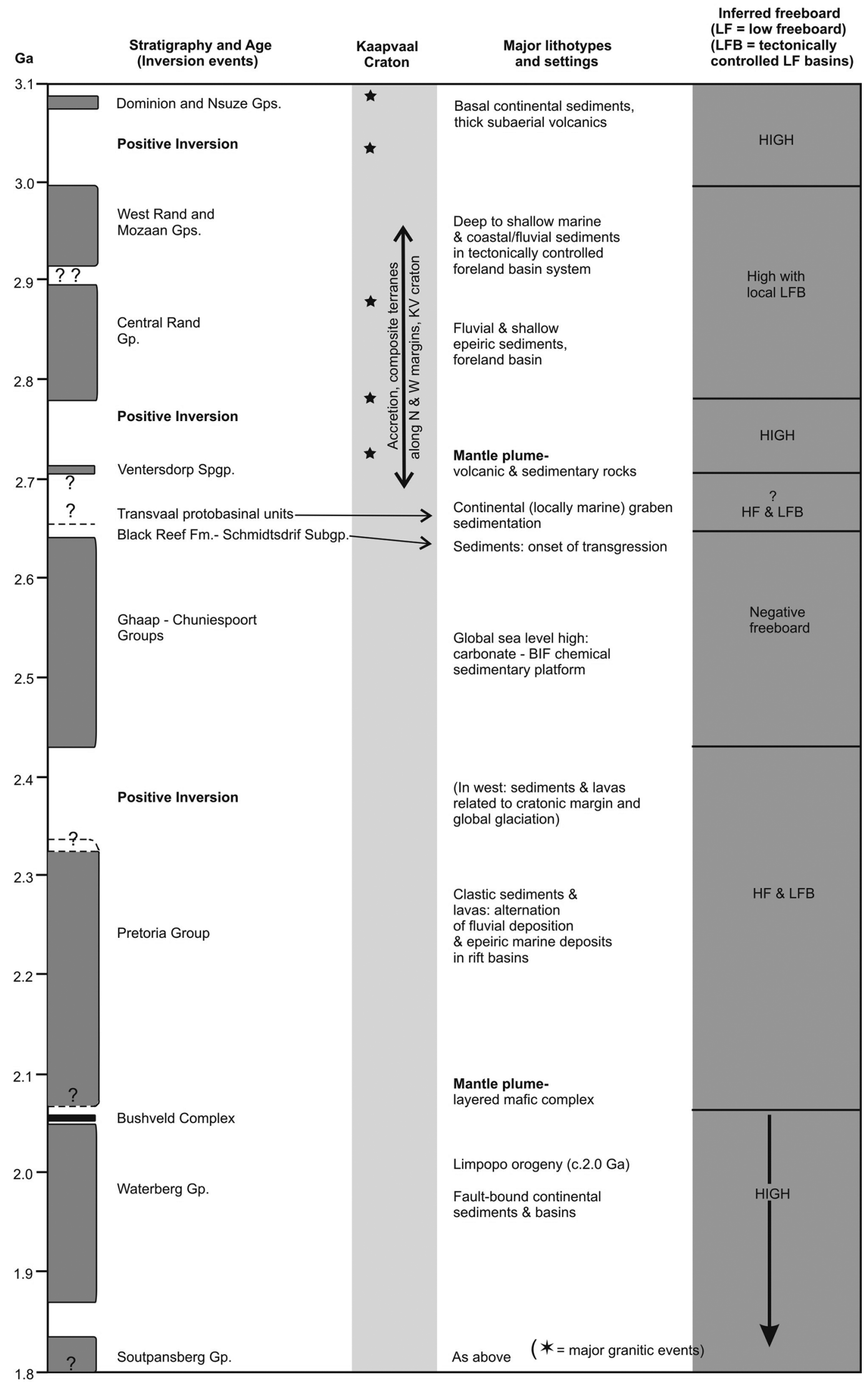


Table 1. Generalized regional stratigraphy of Karnataka (geographic area which equates to Western Dharwar craton; after Geological Survey of India 2006).

\begin{tabular}{|c|c|c|c|}
\hline Eon, era, or epoch & $\begin{array}{l}\text { Suite, assemblage, or } \\
\text { general formation }\end{array}$ & Group formation & Lithology \\
\hline $\begin{array}{l}\text { Late Archaean to } \\
\text { Palaeoproterozoic to Late } \\
\text { Archaean, 2900-2600 Ma }\end{array}$ & Dharwar Supergroup & $\begin{array}{l}\text { Chitradurga Group, Vanivilas } \\
\text { Subgroup, 2700-2600 Ma }\end{array}$ & $\begin{array}{l}\text { Polymict conglomerate, cross-bedded quartzite, } \\
\text { pelite, stromatolitic carbonates, biogenic } \\
\text { chert, BIF, and manganese formations } \\
\text { (Ingaldahl volcanic, tholeiitic basalt, rhyolite } \\
\text { suite) }\end{array}$ \\
\hline \multirow{2}{*}{$\begin{array}{l}\text { Late Archaean, }<3000 \mathrm{Ma} \\
\text { Middle Archaean, } 3000 \mathrm{Ma}\end{array}$} & Peninsular Gneiss-I & - & Tonalite-trondhjemite-granodiorite \\
\hline & - & Sargur Group & $\begin{array}{l}\text { Ultramafic rocks of Holenarsipur, Nuggihalli; } \\
\text { serpentinized peridotitic komatiites, BIFs/ } \\
\text { garnet-biotite schist with kyanite, } \\
\text { sillimanite, and staurolite; marble, barites, } \\
\text { and others }\end{array}$ \\
\hline $\begin{array}{l}\text { Lower to middle Archaean, } \\
3000 \mathrm{Ma}\end{array}$ & Older gneiss & Gonur Gneiss - Hunsur Gneiss & $\begin{array}{l}\text { Trondhjemite, granodiorite, grey banded } \\
\text { biotite orthogneiss }\end{array}$ \\
\hline
\end{tabular}

Note: BIF, banded iron formation.

$\left(\mathrm{Ri}=0.701 \pm 0.001\right.$, where $\mathrm{Ri}$ represents $\left.\left({ }^{87} \mathrm{Sr} /{ }^{86} \mathrm{Sr}\right)_{i}\right)$. The Chitradurga Granite is known to intrude the Chitradurga Group (Dharwar Supergroup) and has yielded a lead isochron age of $2605 \mathrm{Ma}$ and $\mathrm{Rb}-\mathrm{Sr}$ age of $2500 \mathrm{Ma}$. The intrusive granitoids, therefore, fix a minimum age for the supracrustals of the region between 2605 and $3200 \mathrm{Ma}$ The supracrustals are probably older than $3315 \mathrm{Ma}$ or possibly even older than $3800 \mathrm{Ma}$. The metamorphic grade varies from amphibolite to lower granulite facies; some of the older greenstone belts such as Holenarsipur, Nuggihalli, and Krishnarajpet are metamorphosed to greenschist facies, but upper amphibolite facies rocks are found at their peripheries (Naqvi and Rogers 1987).

The Sargur enclaves consist largely of a supracrustal assemblage of quartzite, carbonate, metapelite, and iron formation, as well as high-grade mafic rocks. It is possible that some of the older belts in the south have been intruded by older members of the PGC. Janardhan and Srikantappa (1975) proposed that deforma-tion in Sargur enclaves in the southern part of the craton was coincident with emplacement of the gneisses. Enclaves may be a few kilometres in width and tens of kilometres in length and may also possibly be considered as very old members of the PGC ultramafic-mafic-anorthosite suites (Naqvi 1981).

Rocks of ultramafic, gabbroic, noritic, and anorthositic composition, BIFs, as well as high-grade metapelites are common in the high-grade southern schist belts. The ultramafic flows show spinifex textures, and there is a near-absence of arenaceous sedimentary rocks; these belts contain only $1.3 \%$ siliceous sedimentary rocks, which exhibit $\delta^{18} \mathrm{O}$ ratios of $+12.5 \%$, suggesting a metamorphosed chert origin (Naqvi 1981). Folds tend to have steep plunges, and they may be doubly plunging in many cases. Three episodes of deformation has been recorded in these pre-3000 Ma greenstone belts, resulting in complex and doubly plunging folds, accentu-ated by differential uplift and subsidence (Chadwick et al. 1978). The Sargur Supergroup is complex and can be regarded as an orthoquartzite-carbonate-pelite association (a platformal assemblage) typical of an ensialic basin.

The basement to the Sargur Group remains problematic. An older sialic basement, which is indistinguishable from the rest of the gneissic complex (i.e., the ca. 3.0 Ga PGC), can possibly be considered as the base of the Sargur Group; however, Ramakrishnan and Swaminatha (1976) and Swami Nath and Ramakrishnan (1981) contend that the basement for the Sargur is not yet recognized. In contrast to this view, some of the older greenstone belts were intruded by the $\sim 3.4 \mathrm{Ga}$ Gorur gneisses near Katya in the western part of the Holenarsipur schist belt (Beckinsale et al. 1980; Naqvi 1981). The oldest ages documented in the Dharwar craton include a 24-point $\mathrm{Rb}-\mathrm{Sr}$ whole-rock isochron of $3315 \pm 13 \mathrm{Ma}(\mathrm{Ri}=0.7006)$ and an 11-point $\mathrm{Pb}-\mathrm{Pb}$ isochron of $3305 \pm 13 \mathrm{Ma}$ for the Gorur-Hassan tonalitic gneisses of the Holenarsipur region (Glikson 1979). The Gorur-Hassan gneiss carries inclusions of metamorphosed supracrustals, which are believed to be xenoliths by Hussain and Naqvi (1983), but are considered as tectonic inclusions by Beckinsale et al. (1980). It is necessary to establish the exact nature of these inclusions for understanding the relative age relationship of the supracrustals (and whether they are Sargur equivalents) and these apparently older gneisses. Relict ages of granitoids as old as 3300 Ma have been found in pebbles in the Dharwar Supergroup conglomerates (Venkatasubramanian and Narayanaswamy 1974), supporting the possibility of an older basement. Drury et al. (1984) have reported an $\mathrm{Rb}-\mathrm{Sr}$ isochron age of $3280(\mathrm{Ri}=0.7009 \pm 12)$ for the Hirebelle gneisses in the Western Ghat region of Karnataka (WDC).

In addition to the younger Dharwar Supergroup schists, Naqvi (1981) identified two types of schist (greenstone) belts within the older Sargur Group: (1) the Holenarsipur-Nuggihalli type dominantly consisting of ultramafic-anorthositic suites (mainly volcanic), metapelites, cherts, and iron formations metamorphosed up to amphibolite facies; (2) the Javanahalli type - represented by meta-arkose (paragneisses) at the base, succeeded by arkose, amphibolite (metapelites), calc-silicates, metavolcanics, and fuchsite quartzite. However, the status of the Javanahalli schist belt is uncertain because of its tectonic contacts with the younger Chitradurga Group (upper unit, Dharwar Supergroup) schist belt to the west, and the absence of any known unconformities. To add to the confusion, the Javanahalli schist belt has been correlated with both the Bababudan Group (lower unit, Dharwar Supergroup) and the Chitradurga Group (Ramakrishnan 1980). Despite Naqvi et al. (1980) and Naqvi and Rogers (1987) proposing the Javanahalli as an intermediate (Dharwar) group based on lithologies which were compared to the Bababudan-Chitradurga groups, the metamorphic grade is equivalent to the older Holenarasipur Group (Naqvi et al. 1980; Narayana et al. 1983). The usefulness of the Javanahalli type can thus be questioned seriously.

The Peninsular Gneiss (PGC) together with the Sargur supracrustal remnants, enclaves, and high-grade greenstone belts is thought to have formed the basement of the younger Dharwar rocks overlying a marked basal unconformity (Ramakrishnan and Swaminatha 1976; Swami Nath and Ramakrishnan 1981). Since the major event of Peninsular Gneiss intrusion is dated at around 3.0 Ga, the Sargur Group of rocks probably belong to the early-middle Archaean. After the formation of the older schist belts, a regional and major crustforming event took place around 3.0 Ga to form much of the PGC (Ramakrishnan and Swaminatha 1976; Naqvi and Rogers 1987). Rb-Sr 
Table 2. Generalized stratigraphic sequence of Dharwar Supergroup (after Swami Nath and Ramakrishna 1981).

\begin{tabular}{lll}
\hline Group & Formation & Rock type \\
\hline Chitradurga Group & Hiriyur & Predominantly greywacke with Fe-Mn chert, polymict conglomerate \\
& Ingaldahl & Quartz chlorite schist, argillite with Fe-Mn chert and metabasalt \\
Unconformity & Vanivilas & Fe-Mn formations, carbonates, phyllite, and quartzite with conglomerate \\
Bababudan Group & Unconformity & Unconformity \\
& Mulaingeri & Fine clasts \\
& Santaveri & Bimodal volcanic, quartzites \\
& Allampur & Quartzites with igneous association \\
& Kalasapura & Basic volcanic with quartzite and conglomerates \\
\hline
\end{tabular}

whole-rock and mineral isochrons suggest two major events regarding origin of granites and migmatites, one at 2900-3000 Ma and another at $2500-2600 \mathrm{Ma}$; the $2600 \mathrm{Ma}$ event is also reflected in the charnockites (Venkatasubramanian and Narayanaswamy 1974). The PGC is a complex suite occupying vast areas of the Western Dharwar craton (Drury et al. 1978; Naqvi 1981). The major rock type is tonalitetrondhjemite-granodiorite (TTG) gneiss with minor granodioritegranitic varieties.

The younger schist belts belonging to the Dharwar Supergroup are characterized by metamorphism predominantly of greenschist facies but locally up to epidote-amphibolite or lower amphibolite facies towards the south of the WDC. They contain an abundance of clastic and quartzose sedimentary rocks, a comparatively high proportion of sedimentary to volcanic rocks, and conglomerates containing clasts of underlying gneisses. The Dharwar schists were deposited on a peneplained basement of peninsular gneisses as evidenced by the latter supermature basal quartz pebble conglomerates. This regional unconformity is marked by an uraniferous gold- and pyrite-bearing oligomict quartz pebble conglomerate. Typical rock types of the Dharwar greenstone belts are arenite, shales, basalts to rhyolites, cherts, phyllites, and carbonates. Well-known examples of the Dharwar Supergroup are the Chitradurga, Bababudan, Shimoga, and Western Ghat (greenstone) belts (Fig. 1).

Stratigraphically, the Dharwar Supergroup is divided into the lower Bababudan Group and the upper Chitradurga Group, separated by an unconformity (Table 2) ( Swami Nath et al. 1976; Swami Nath and Ramakrishnan 1981). Radiometric data constrain the Bababudan and Chitradurga groups as having formed at ca. 3.0-2.55 Ga(Crawford 1969; Venkatasubramanian and Narayanaswamy 1974; Taylor et al. 1984). The volcanic rocks of the Bababudan Group are subaerial, typically bimodal, whereas those in the Chitradurga Group are submarine, bimodal to polymodal. Trace elements and rare-earth elements (REE) analysis suggests passive margin, foreland, back-arc, and intra-arc environments for their genesis (Chadwick et al. 2000). Sedimentological studies on the quartz pebble conglomerates of the Bababudan Group suggest stability of the crust by early Archaean. One of the conspicuous features of the Dharwar succession is the occurrence of extensive deposits of limestone, manganese, and iron formations. Detailed geochemical studies on BIF including REE characteristics, lanthanum spiking, and strong positive europium anomalies of the Kudremukh, Sandur, Chitradurga, Kushtagi, and Kolar schist belts suggest Fe, Mn, and Au formation may have been contributed largely by hydrothermal activity related to submarine volcanism in the Dharwar Sea (Arora 1991; Manikyamba et al. 1993; Gnaneswar Rao and Naqvi 1995; Raju 2009).

The sequence of rock types in the Bababudan Group starts with a quartz pebble conglomerate (QPC) consisting of detrital pyrite, uraninite, and gold (Viswanatha and Ramakrishnan 1981; Arora 1991). Succeeding mature quartzites exhibit current bedding and ripple marks indicating stable shelf conditions. The quartzites are interbedded with mid-ocean ridge basalt (MORB)-type volcanic rocks (Bhaskara Rao 1980; Arora 1991). These rocks are overlain by a very thick sequence of BIFs, which is followed by schist, greywacke, and conglomerate. The Bababudan and Chitradurga groups are separated by iron-formation-rich horizons known as BIF-I (Chadwick et al. 1981b). However, Ramakrishnan and Viswanatha (1981) was of the opinion that the two groups are separated by Aimangala, Kaldurga, and Talya conglomerates in the Chitradurga schist belt. However, as the conglomerates exhibit disrupted framework and suggest deposition as mudflows within the basin, they may not indicate a break in sedimentation and therefore cannot be taken as a division between the two (Naqvi 1978).

The concept of Radhakrishna (1983) that the Bababudan and Chitradurga groups are coeval, representing different facies, namely platformal and deeper ocean, is not supported by geochronological data. The major rock types in the Chitradurga Group consist of greywacke-type conglomerates with disrupted framework, greywackes, phyllites and BIFs, cherts, shales, associated with a variety of volcanic rocks ranging from basalts to rhyolites. The entire sequence suggests an active continental margin setting (Naqvi et al. 1988). BIFs, manganese formations, and stromatolites are abundant in this group (Srinivasan and Sreenivas 1972; Gnaneswar Rao and Naqvi 1995). The Chitradurga schist belt thus presents a rather simple history of sedimentation and volcanism in a subsiding basin. The major structure of the belt can be viewed as a second-generation antiform refolding an earlier syncline. At least three generations of folding have been recognized. Firstgeneration folds are isoclinal and reclined, with axial plane schistosity parallel to bedding except at fold hinges. The F2 folds are coaxial with F1 folds, open to isoclinal, accompanied by development of granulation cleavages, and cause dispersion of F1 axes. The F3 folds in the Chitradurga belt are broad warps on the limbs of both F1 and F2 folds. This complex structure results in BIF being repeated structurally at several places in the sequence (Naqvi 1973).

\section{Eastern Dharwar craton (EDC)}

Deformation and metamorphism of the greenstone belts in the EDC are sufficiently intense so that stratigraphic relationships are not clear; these belts tend to be engulfed in at least some phases of the peninsular gneisses. Several high-grade schist belts occur in a broad area north of Kolar, including the PenukondaRamagiri, Pamidi, Hutti-Maski, Hungund, and Sandur belts (Viswanatha and Ramakrishnan 1976; Roy and Biswas 1979). More than $90 \%$ of the rocks are metabasalts, andesites, and minor silicic volcanic rocks metamorphosed to greenschist-amphibolite facies (Roy and Biswas 1979; Anantha Iyer 1983). Talc-chloriteactinolite schists and serpentine-bearing lithologies, presumably meta-ultramafic rocks, are also present. Most rocks in the schist belts of the East-ern Dharwar craton are similar to the Western Dharwar craton, and both include also BIF, quartzite, mica schist (metapelite), and calc-silicate. The proportion of metasedimentary rocks in the EDC, however, is much less, compared with the WDC, and amphi-bolite, cordierite-bearing schist, and Mn-rich calc-silicate are well studied in the EDC. The gneisses in both the eastern and western parts of the craton are lithologically similar, and these have un-dergone similar patterns of deformation. TTG peninsular gneisses of the Bangalore area of the EDC show negative Nd values ( -5 to-8) at $2540 \mathrm{Ma}$, with depleted mantle TDM Nd model ages ranging from 3100 to 3400 Ma using a depleted mantle model (Jayananda 
et al. 2000). These model ages are similar to that defined for the 3300 Ma peninsular gneisses in the Western Dharwar craton (Peucat et al. 1993).

Predominantly east-west-trending dykes are widespread throughout the eastern part of the Dharwar craton (Drury et al. 1984; Kumar et al. 2012). Reported ages of dykes and sills (along with flows) in the Cuddapah basin are about $1500 \mathrm{Ma}$. The deformed, metamorphosed, and intruded sequences of gneissic-greenstone belt crystalline rock in several places are overlain by largely undeformed younger sedimentary successions. Three major Proterozoic sedimentary basins in the EDC include the Cuddapah, Bhima, and Kaladgi; while the former exhibits minor folding and metamorphism, the other two basins are largely undeformed.

\section{Discussion: evolution of Dharwar craton (and comparison with Kaapvaal craton)}

\section{Western Dharwar craton}

Based on the framework provided by Ramakrishnan and Vaidyanadhan (2008) and Meert et al. (2010) and applying recent literature (including new age data) on the Dharwar craton encapsulated in a special issue of Precambrian Research (vol. 227, Jayananda et al. 2013 and references therein), a preliminary evolution of the WDC can be put together. An initial genetic model, for the basement rocks and Sargur Group of the WDC, can be postulated as comprising several events:

(1) At ca. $3.35 \mathrm{Ga}$, within an overall mantle plume setting, a set of oceanic plateaux, komatiitic to tholeiitic in composition, is thought to have formed upon oceanic crust; subsequently these accreted (see No. 2 in this list). This mafic association reflects the lower part of the Sargur Group. Latest age data (Hokada et al. 2013 and references therein) for detrital zircons in mafic lithologies within this group gives 3.58-3.13 and 3.23 $\mathrm{Ga}$, while felsic volcanics (upper Sargur Group) date di-rectly at $3298 \pm 7 \mathrm{Ma}$. From the area of the Gadag greenstone belt in the north of the WDC, there is evidence for $3.6 \mathrm{Ga}$ protocrust and a major crustal growth episode (i.e., the Pen-insular Gneiss complex, PGC) at ca. 3.36 Ga (Sarma et al. 2012 and references therein).

(2) Circa 50 megayear after ocean plateau formation, subduction complexes are postulated to have formed as accretion occurred, forming the upper Sargur Group felsic to mafic sequences. The latter formed from accreting plateau complexes and lithospheric mantle root, which are assumed not to have been subductable.

(3) Protoliths for the formation of the PGC are thought to have been deeper-sourced intrusions from beneath the plateau remnants, at ca. $3.35 \mathrm{Ga}$ (references in Sarma et al. 2012 give 3.36-2.7 Ga). Formation of the Peninsular Gneiss basement was thus essentially contemporaneous with evolution of the ultramafic plateau complexes of the lower Sargur Group.

(4) High-grade metamorphism of the Sargur Group occurred at 3.13-2.96 Ga, through the emplacement of the Peninsular Gneiss.

When this model is compared with that envisaged for the Kaapvaal craton of South Africa, a different scenario is seen in the latter. For Kaapvaal, sequential accretion of complex small terranes of arc lithologies and TTG (tonalite-trondhjemitegranodiorite) appears to have dominated, and ages thus vary across Kaapvaal with ongoing accretion (e.g., de Wit et al. 1992; Eglington and Armstrong 2004; Zeh et al. 2009; Bumby et al. 2012 and references therein). There is thus no common-age TTGgreenstone basement (cf. Peninsular Gneiss) as in the WDC, inferred to have formed through an ocean plateau-arc model.

The next major event in the WDC was formation of the Dharwar Supergroup (ca. 2900-2600 Ma), comprising the Bababudan Group (succession 1 or lower Dharwar Supergroup; preserved in three schist belts), with a profound basal unconformity, and the overlying Chitradurga Group (successions 2 and 3; upper Dharwar). The postulated succession of deposits and events is given as follows:

(1) Deposition of a basal quartz pebble conglomerate (QPC; Kartikere conglomerate) was succeeded by quartzite-basalt alternations and minor gabbroic sills, BIF, and phyllites, together making up "succession 1" (Swami Nath and Ramakrishnan 1981; Arora et al. 1994; Arora and Naqvi 1993; Bhusan and Sahoo 2010). The latter is interpreted as braided fluvial deposits and subaerial lavas, and according to Hokada et al.'s (2013) age data, deposition occurred at $<3.14 \mathrm{Ga}$; these rocks most likely were deposited between ca. 2.91 and $2.72 \mathrm{Ga}$.

(2) Deposition of a polymict conglomerate - wacke - pelite quartzite - carbonate - manganese formation - BIF assemblage occurred at the margin of the Dharwar basin (to form the Vanivilas Subgroup). The approximately coeval and widespread Ingaldhal Volcanics comprised a pillow lava - pyroclastic (bimodal volcanics) - chert - BIF assemblage, laid down in the interior of the basin. These two assemblages make up "succession 2"; age data from Hokada et al. (2013) for the Lower Chitradurga Group indicates deposition at $<2.72 \mathrm{Ga}$.

(3) "Succession 3" (cf. Ranebennur Subgroup) comprises a greywacke - phyllite - BIF - polymict conglomerate - volcanic succession. Felsic volcanics in the succession date directly at $2676 \pm 10,2677 \pm 3,2665 \pm 15 \mathrm{Ma}$, while detrital zircons from sandstones overlying the Ranebennur Subgroup give ages $>2.63 \mathrm{Ga}$ (Hokada et al. 2013). Across seven distinct green-stone belts, greenstone magmatism is dated at 2.7-2.6 and 2.58-2.54 Ga, approximately coincident with ca. $2.61 \mathrm{Ga}$ po-tassic granite magmatism in the WDC (Hokada et al. 2013 and references therein).

Within the Gadag greenstone belt, which is the northern extension of the Chitradurga belt, late kinematic basinal sediments contain detrital zircons $<2547 \pm 5 \mathrm{Ma}$, and the age of the underlying greenstone volcanics is $2588 \pm 10 \mathrm{Ma}$, while later Au mineralization dates at $2522 \pm 6 \mathrm{M}$ a (Sarma et al. 2012). Between the late kinematic sedimentation and Au mineralization, the terrane was deformed, metamorphosed, and uplifted. There is thus a pro-longed history of juvenile and recycled crustal components in the Gadag Belt (Sarma et al. 2012 and references therein).

In general, the western margins of the Dharwar Supergroup belts display basal unconformities, while eastern margins tend to be tectonized, deformed, and metamorphosed to greenschistamphibolite facies. Isolated granites of $2600 \mathrm{Ma}$ intrude both Dharwar Supergroup and peninsular gneisses; calc-alkaline to highpotassic granitoids intruded at 2.6-2.5 Ga (Sarma et al. 2012 and references therein). It is noted by Hokada et al. (2013) that both parts of the Chitradurga Group (successions 2 and 3 discussed earlier in the text) were metamorphosed together at ca. $2.5 \mathrm{Ga}$, and that this metamorphism is not detected in the Bababudan Group (succession 1) and Sargur Group. According to Jayananda et al. (2013), the WDC cratonized close to $2.61 \mathrm{Ga}$ and was moderately deformed between widely spaced shear zones thereafter.

Comparing the Dharwar Supergroup with evolution of the Kaapvaal craton (e.g., Bumby et al. 2012, for a recent relevant review of Precambrian supracrustals, and references therein), succession 1 can possibly be considered as an approximate Witwatersrand Supergroup (Fig. 2) age equivalent, but in contrast to the latter's predominant shallow-marine to fluvial clastic sedimentary rocks, the Bababudan Group is a mainly volcanic succession. Succession 2 of the Dharwar Supergroup, comprising mainly chemical shallowmarine sediments and volcanic rocks has possible analogues in the ca. 2.7 Ga Ventersdorp Supergroup (volcanics and lesser immature clastic sedimentary deposits) and the lower part of the Transvaal Supergroup (cf. Chuniespoort-Ghaap groups, of dolomite and BIF; Bumby et al. 2012) from Kaapvaal (Fig. 2). However, the essentially 
shallow-marine deposits of succession 2 (lower Chitradurga Group) of the WDC (Fig. 3) contrast with the subaerial nature of the Ventersdorp volcano-sedimentary lithologies; i.e., there was probably not a major plume beneath the WDC at ca. $2.7 \mathrm{Ga}$, although the Ingaldhal Volcanics might have been plume related (?). Succession 3 (upper Chitradurga Group) of the Dharwar Supergroup (Fig. 3), while comparing favourably lithologically to the Pretoria Group (upper Transvaal Supergroup of Kaapvaal; Eriksson et al. 2006b), is much older. Age-lithological relationships of the Dharwar and Kaapvaal cratons are thus rather different over the ca. 2.7-2.6 Ga period. Major granitization and cratonization in Kaapvaal occurred much earlier than in the WDC - what is really important is that cratonization in Kaapvaal was advanced enough prior to accretion of complex terrains with gold sources, to accommodate a flexural foreland basin setting for the ca. 3.1-2.8 Ga Witwatersrand Supergroup depository (Fig. 2); this would only have been possible on the WDC after ca. 2.61 Ga (Fig. 3).

\section{Eastern Dharwar craton}

A recent summation of the basic geology of the Eastern Dharwar craton (EDC) is provided by Meert et al. (2010 and references therein) who see it as essentially composed of the Dharwar Batholith (cf. PGC; mainly granitic gneisses), greenstone belts, minor kimberlite, and lamproite intrusives, and basins dating from the Middle Proterozoic. The greenstone belts (2700-2600 Ma; some gold-bearing) (Fig. 3) are made up essentially of pillowed basalts, pyroclastics, and BIF in their central parts, with thin marginal western portions consisting of quartzite, marble, pelite, and manganese formation; ultramafic schists are subordinate and there are uncommon layered complexes. Along the eastern margins of most greenstone belts, felsic volcanics are associated with polymict conglomerates and minor BIF to form a marker horizon. Basement-cover unconformities are not found, and the greenstone belts are intruded and enveloped by voluminous granitoids (2600-2500 Ma) of granodiorite-adamellite-tonalitegranite composition. Both granitic suites and greenstones have a strongly linear pattern, orientated mainly northwest-southeast, analogous to the WDC. Ages of the Dharwar Batholith vary from 2700 to $2500 \mathrm{Ma}$, and these tend to decrease from west to east. Gneissic protolith ages of $>2.9 \mathrm{Ga}$ are inferred from zircons within younger dykes intruding the granitic gneisses.

More recently, and succinctly, Jayananda et al. (2013) describe the EDC as encompassing 2.7-2.55 Ga TTG gneisses and migmatites and minor remnants of 3.0-3.38 Ga crust, several $2.7-2.55 \mathrm{Ga}$ greenstone belts, and voluminous $2.56-2.50$ Ga calc-alkalinepotassic plutonic intrusions (of which the Closepet Batholith is the most spectacular). Most EDC greenstone belts have sheared intrusive contacts with syntectonic Neoarchaean plutons. The greenstones are dominated by volcanic rocks (minor komatiite, high-Mg basalt, andesite, adakite, rhyolite) and BIF. Jayananda et al. (2013) discuss the merits of two genetic models for the EDC, preferring the second:

(1) A plume-type model (plume melted depleted mantle), wherein the Closepet Granite is seen as a batholith, to form the EDC through essentially "vertical tectonics".

(2) An east-to-west accretionary model of island arcs, or of an already-formed arc-granitic whole-batholith terrane, again from east to west, onto the WDC is postulated. In this model, the Closepet Granite is interpreted as having accreted onto the WDC. In this arc accretion model, the Eastern Ghats mobile belt (eastern margin of the EDC) is interpreted as the closure point during amalgamation of the EDC with the WDC.

\section{Towards a coherent genetic model for the Dharwar craton}

The second model postulated in the preceding text encompasses also a coherent genesis for the entire craton (Fig. 4). Jayananda et al. (2013) further see the EDC as being subsequently rejuvenated by massive Neoarchaean magmatism and flowing lat- erally against the WDC. A major thermal event close to $2.51 \mathrm{Ga}$ is thought to have affected the entire Dharwar craton. In a unitary Dharwar craton scenario, thus, there are two major volcanic episodes in the DC: (1) one at ca. $2.7 \mathrm{Ga}$, which was a major largely mafic greenstone volcanism event, with evidence supporting this in both WDC and EDC - this volcanism was contemporaneous with emplacement of TTG suites (cf. PGC or Dharwar Batholith) surrounding the greenstone belts; (2) one at ca. 2.6-2.54 Ga, dominated by intermediate to felsic volcanic rocks, occurred in both WDC $(2.61 \mathrm{Ga}$; associated with emplacement of potassic granites from lower crustal melting) and EDC (2.58-2.54 Ga; coeval and genetically linked to widespread juvenile calc-alkaline magmatism and crustal reworking throughout the EDC) (Fig. 4).

Jayananda et al. (2013) propose an overall combined plume and subduction model to explain Neoarchaean accretion in the EDC. They postulate a central Dharwar terrane (see also Peucat et al. 2013) that accreted to the WDC where the Chitradurga and Hutti greenstone belts lie (now the Chitradurga boundary shear zone), through subduction at 2.74-2.70 Ga. Seaward of this, to the east, they envisage three small plume-fed ocean plateaux (represented by EDC greenstone belts). At 2.7-2.60 Ga, these plateaux, now comprising partly also TTG suite rocks, collided (with subduction separating individual terranes) against each other and the central Dharwar terrane; at $2.56-2.51 \mathrm{Ga}$, they became fully accreted to the already amalgamated central WDC terranes, with formation of widespread granite plutons, including the Closepet Granite in central Dharwar and local TTGs there as well. At 2.51-2.50 Ga, final cratonization of the EDC, central Dharwar, and the WDC occurred (see fig. 20 in Jayananda et al. 2013 for a cartoon version of the overall DC genetic model). Mohan et al. (2013) support this model of Jayananda et al. (2013), and stress the importance of a conver-gent margin tectonic setting for the EDC, the importance of sub-duction processes (with more recycled crust within this inferred subduction framework in the western part of the EDC), and supra-subduction arc settings. They also see a systematic decrease in involvement of older crust from west to east, which concurs with the systematic younging of dated rocks in the EDC in the same direction.

Dey (2013), using the Nd isotope record, finds that both EDC and WDC show evidence of crust formation as far back as $3.5 \mathrm{Ga}$ (however, no rocks of this age have been found yet). In the WDC, the main period of juvenile crust formation was at 3.35-3.0 Ga, derived from depleted mantle, and with crustal recycling. Refertilization (possibly due to subduction-related metasomatism) of mantle underlying the WDC probably occurred in the Mesoarchaean, and from this mantle, extensive mafic volcanism at 2.9$2.6 \mathrm{Ga}$ occurred in the WDC. Major crustal recycling took place in the WDC at 2.7-2.6 Ga. In the EDC, 3.1-3.0 Ga gneissic granites indicate recycling of Palaeoarchaean crust, which was largely destroyed by 2.7-2.5 Ga juvenile crustal addition and extensive recycling of older crust. Dey (2013) also finds good evidence from the $\mathrm{Nd}$ isotope record for a central DC terrane, with its eastern contact with EDC along the line of the Hungund Kushtagi Ramagiri -Kolar schist belts (the same contact as in Jayananda et al. (2013), and discussed earlier in the text).

A comparison of Dharwar craton evolution with that of Kaapvaal suggests that the ca. 2.7 and ca. $2.6 \mathrm{Ga}$ volcanic events in the EDC (and entire DC) can be equated possibly with Kaapvaal's ca. $2.7 \mathrm{Ga}$ Ven-tersdorp plume, and to at least a certain extent with the Transvaal protobasinal volcanism at about 2.67 Ga (Eriksson et al. 2002 and references therein) (Fig. 2). However, there is a big contrast between the EDC-DC and Kaapvaal at ca. $2.5 \mathrm{Ga}$, with tectonically active final accretion of the DC accompanied by voluminous granitic magma-tism, while Kaapvaal, with its inherent stability at this time, was characterized by major epeiric transgression and deposition of chemical sediments (e.g., Eriksson et al. 2006b). It can thus be argued that possibly global thermal-magmatic events (e.g., Eriksson et al. 1999) can be seen fairly easily across both Kaapvaal and Dharwar 
Fig. 3. Schematic geohistory chart of Dharwar craton, comparing Western and Eastern Dharwar (after Hokado et al. 2013; Jayananda et al. 2013).

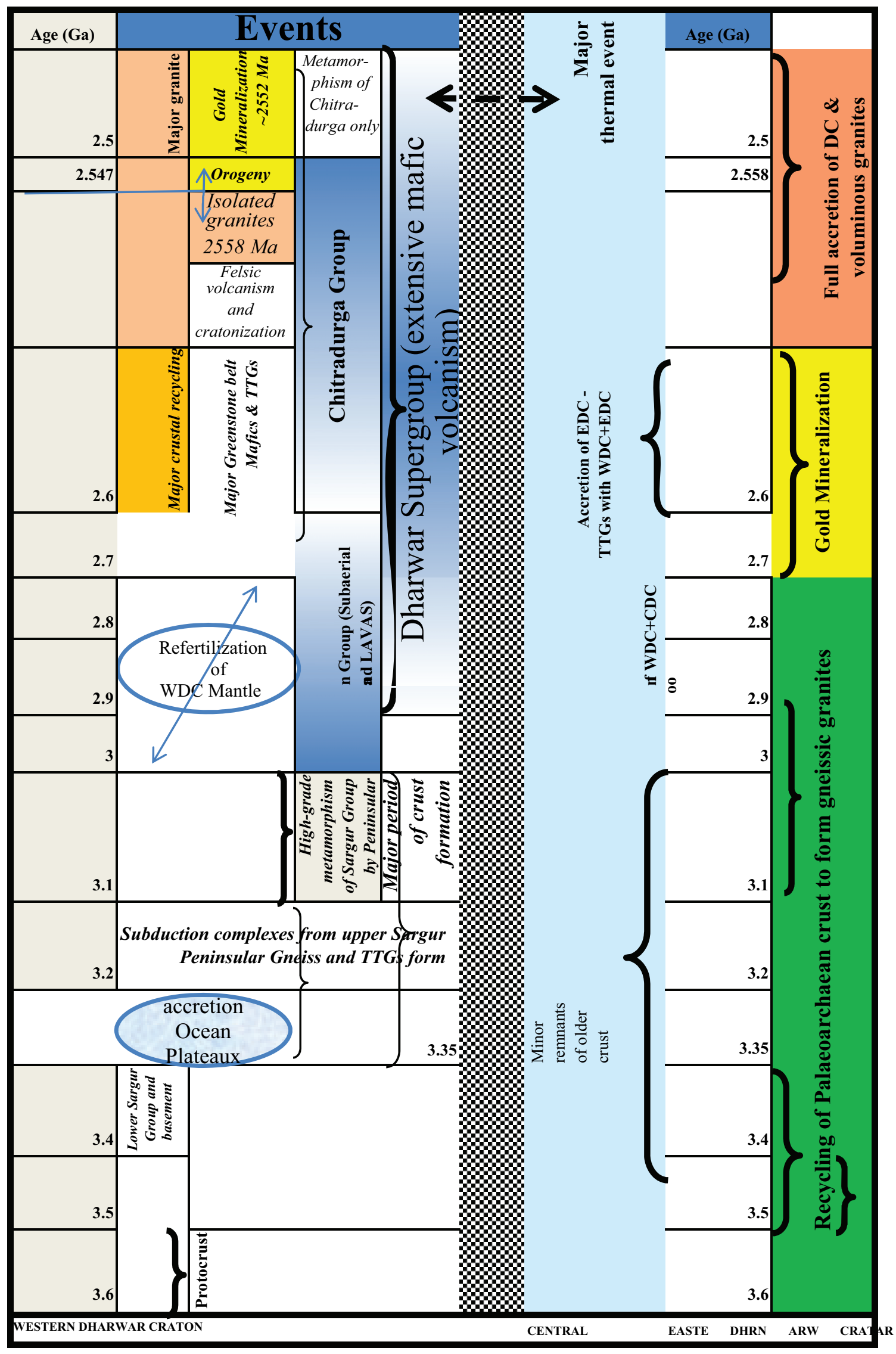


Fig. 4. $(a-d)$ Cartoon depicting a possible tectonic evolutionary model of the Western, central, and Eastern Dharwar cratons (after Jayananda et al. 2013). CSB, Chitradurga boundary shear zone; GBs, greenstone belts.

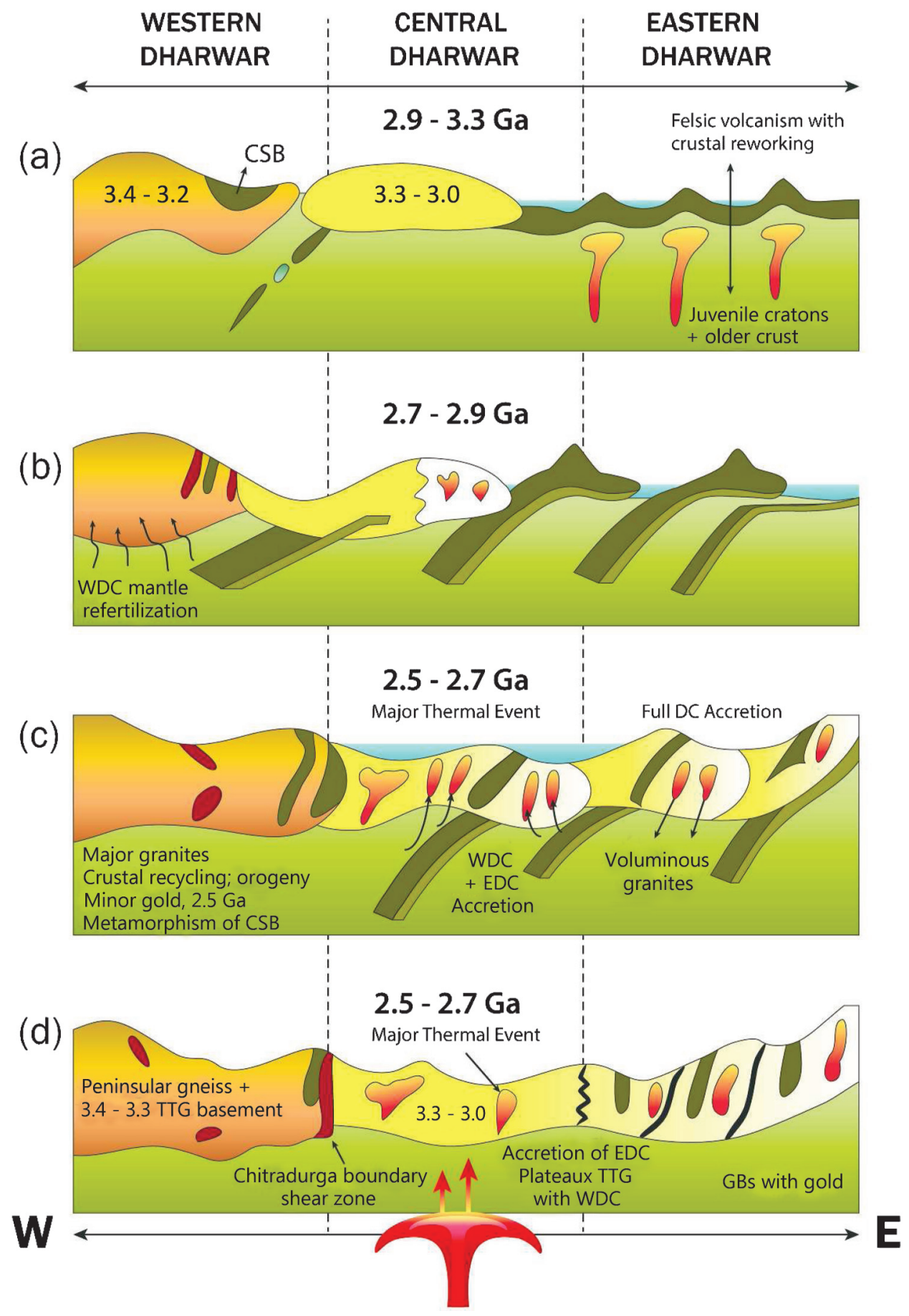

through the "fog" of local tectonic-freeboard-thermal conditions on the two cratons. The much earlier, at least partial, cratonization of the Kaapvaal nucleus by about $3.1 \mathrm{Ga}$ (with only remnants of old crust in EDC and much more in WDC) is the big difference between the two terranes. All three of WDC, EDC, and Kaapvaal have their oldest known crust going back to ca. 3.6-3.5 Ga, but the much earlier onset of at least a measure of cratonization for the Kaapvaal nucleus meant that the accretion there of complex terranes from north and west formed a well-preserved flexural foreland basin accompanied by placer gold mineralization sourced from the accreted greenstone provenances (Catuneanu 2001; Frimmel 2005; Eriksson et al. 2009).
As an alternative to the essentially accretion- and amalgamationbased cratonic evolutionary model espoused earlier in the text for the Dharwar craton, it can be argued that several major geological features in the this craton also support a "classic" Wilson Cycle:

(1) Complex folding events with up to three phases of folding; the association of pillow basalts and chert; structural repetition of BIF. Together and even separately, these observations can be modeled as products of ocean closure concomitant with destruction of these inferred oceans, as in the late stages of a Wilson Cycle. 
(2) Platform-type metasedimentary successions such as quartzitecarbonate-BIF-metapelite and orthoquartzite-carbonate-pelite are strongly reminiscent of passive margin deposits related to rifted margins during continental breakup at the early stage of a Wilson Cycle.

However, both ocean closure and craton-margin rifting can be related to a number of possible tectonic models. The accretion of arc assemblages, small complex terranes, and even small cratonic blocks, as suggested by us for the Dharwar and Kaapvaal cratons, also implicitly include small ocean closures and destruction thereof. Analogously, rifting of cratons through high heat flow and plumes in the Archaean, as also espoused by us here, offer an alternative to a classic Wilson Cycle model and its rifted margin phase.

\section{Conclusions}

Clear evidence for lateral plate movements exists in both Dharwar and Kaapvaal cratons, back to at least $3.3 \mathrm{Ga}$ for the DC, and back to ca. 3.5-3.6 Ga for Kaapvaal (e.g., de Wit et al. 1992; de Wit and Ashwal 1997). While early evolution of WDC greenstones is inferred to reflect predominant mantle thermal or plume processes (ca. $3.35 \mathrm{Ga}$ ), these were soon followed by identifiable subduction and recognizable plate tectonic processes. For the EDC, analogous yet much younger (ca. 2.7$2.5 \mathrm{Ga}$ ) initial plume-related and succeeding plate tectonic processes are interpreted (e.g., the Jayananda et al. 2013 model). While the WDC greenstones exhibit a shared craton-wide geo-chronology, those of the EDC are similar to greenstones on Kaapvaal, with ages varying across the EDC. It is thus evident from these brief comparisons, that the relationships between mantle-thermal or plume processes and early plate tectonic regimes were complex, and that they varied across cratons preserved from the extent Earth; there does not thus appear to be support for a chronologically con-strained gradual change from mantle to plate processes during the early Precambrian evolution of cratons (or at least the two discussed here). Early greenstones and almost coeval granitoid (TTG) assem-blages on WDC, EDC, and Kaapvaal had complex spatial and chrono-logical relationships, yet the assemblages obviously share a common genesis. While Kaapvaal appears to have undergone accretion of complex terranes comprising not just greenstones (cf. arcs and ocean plateau lithologies) but also TTG and even granitic rocks at ca. 2.9-2.8 $\mathrm{Ga}$, early accretion within the Dharwar craton was characterized more by arc and plateau lithologies, with formation of TTG gneisses very soon after; however, the inferred central Dharwar terrane is analogous to those terranes accreting to the Kaapvaal nucleus.

While there is thus a reasonable case to be made for an early onset of recognizable plate tectonics on both Kaapvaal and Dharwar cratons, the same cannot be said of the Wilson Cycle or supercontinent cycle. Neither Kaapvaal nor Dharwar cratons can be reconciled with the concept of either a "supercraton" or a "supercontinent" (as discussed at the beginning of this paper), as both were relatively small and both later amalgamated with other cratonic terranes to form what could best be described as "continents". As to possible breakup and dispersal of either Dharwar or Kaapvaal cratons once formed in the Mesoarchaean to Neoarchaean, while both exhibit extensive shallow-marine deposits with associated mafic volcanic successions (e.g., Dharwar Supergroup on the DC and the lower Transvaal Supergroup on Kaapvaal), neither exhibit any evidence for formation of juvenile crust or mid-ocean ridge development, nor for formation and separation of daughter fragments. It would thus appear that the Wilson Cycle was not yet operative, possibly due to small cratonic dimensions (and thus a less intense effect of thermal blanketing) rather than any lack of requisite plate movement regimes. The concept of cratonic scale might possibly have been important for onset of the Wilson Cycle. For Kaapvaal, the earlier (and equally shallow-marine-dominated) Witwatersrand basin-fill (with minor mafic volcanics) formed under a compressive tectonic regime (flexural retroarc foreland basin; Catuneanu 2001), and there was thus no question of cratonic breakup during that basin's life

cycle.

\section{Acknowledgements}

P.G.E. thanks both the National Research Foundation and the University of Pretoria, South Africa, for research funding, and Thino Rajab for drafting. This research has also been supported by grant entitled RRF and SHORE (PSC0205) funded by the CSIR, India. The authors are grateful for the sage advice of three anonymous reviewers and special volume Editor Ali Polat.

\section{References}

Anantha Iyer, G.V. 1983. Trace and REE geochemistry of the Archaean greenstone-granite and gneiss-granulite regions in the southern Indian shield. Memoir of the Geological Society of India, 4: 169-182.

Arora, M. 1991. Geology, geochemistry and tectonic setting of conglomerates and quartzites of Bababudan schist belt, Karnataka nucleus, India. Ph.D. thesis, Department of Geology, Aligarh Muslim University, Aligarh.

Arora, M., and Naqvi, S.M. 1993. Geochemistry of Archaean arenites formed by anoxic exogenic processes: An example from Bababudan schist belt, India. Journal of Geological Society of India, 42: 247-268.

Arora, M., Khan, R.M.K., and Naqvi, S.M. 1994. Composition of the middle and late Archean uppercontinental crust as sampled from Kaldurga conglomerate, Dharwar craton, India. Precambrian Research, 70: 93-112. doi:10.1016/ 0301-9268(94)90022-1.

Aspler, L.B., and Chiarenzelli, J.R. 1998. Protracted breakup of Kenorland, a Neoarchean supercontinent? Geochronologic, tectonostratigraphic and sedimentologic evidence from the Paleoproterozoic. Sedimentary Geology, 120: 75-104. doi:10.1016/S0037-0738(98)00028-1.

Beckinsale, R.D., Drury, S.A., and Holt, R.W. 1980. 3300-Myr old gneisses from the South Indian Craton. Nature, 283: 469-470. doi:10.1038/283469a0.

Bhaskara Rao, Y.J. 1980. Geology and Geochemistry of metavolcanics and associataed rocktypes form Bababudan belt and late Archean Crustal evolution in Karnataka. $\mathrm{Ph}$.D. thesis, Department of Geology, Osmania University, Hyderabad.

Bhaskara Rao, Y.J, Beck, W., Rama Murthy, V., Nirmal Charan, S., and Naqvi, S.M. 1983. Geology, geochemistry and age of metamorphism of Archaean grey gneisses around Channarayapatna, Hassan district, Karnataka, South India. Memoir of the Geological Society of India, 4: 309-328.

Bhusan, S.K., and Sahoo, P. 2010. Geochemistry of Clastic Sediments from Sargur Supracrustals and Bababudan Group, Karnataka: Implications on Archaean Proterozoic Boundary. Journal of the Geological Society of India, 75: 829840. doi:10.1007/s12594-010-0068-y.

Bleeker, W. 2003. The late Archean record: a puzzle in ca. 35 pieces. Lithos, 71: 99-134. doi:10.1016/j.lithos.2003.07.003.

Bleeker, W., and Ernst, R. 2006. Short-lived mantle generated magmatic events and their dyke swarms: the key to unlocking Earth's palaeogeographic record back to $2.6 \mathrm{Ga}$. In Dyke Swarms - Time Markers of Crustal Evolution. Edited by E. Hanski, S. Mertanen, T. Rämö, and J. Vuollo. CRC Press, Taylor and Francis, London. pp. 3-26.

Bumby, A.J., Eriksson, P.G., Catuneanu, O., Nelson, D.R., and Rigby, M.J. 2012. Meso-Archaean and Palaeo-Proterozoic sedimentary sequence stratigraphy of the Kaapvaal craton. Marine and Petroleum Geology, 33: 92-116. doi:10. 1016/j.marpetgeo.2011.09.010.

Button, A. 1976. Transvaal and Hamersley basins — review of basin development and mineral deposits. Minerals Science and Engineering, 8: 262-292.

Catuneanu, O. 2001. Flexural partitioning of the Late Archaean Witwatersrand foreland system, South Africa. Sedimentary Geology, 141-142: 95-112. doi:10. 1016/S0037-0738(01)00070-7.

Chadwick, B., Ramakrishan, M., Viswa Natha, M.N., and Srinivasa Murthy, V. 1978. Structural studies in the Archaean Sargur and Dharwar Supracrustals rocks of the Karnataka Craton. Journal of Geological Society of India, 19: 531-549.

Chadwick, B., Ramakrishnan, M., Viswa Natha, M.N., and Srinivasa Murthy, V. 1981a. Structure and Metamorphic relations between Sargur and Dharwar Supracrustals rocks and peninsular gneisses in Central Karnataka. Journal of Geological Society of India, 22: 557-569.

Chadwick, B., Ramakrishnan, M., and Viswa Natha, M.N. 1981b. The stratigraphy and structure of the Chitradurga region: An illustration of cover-basement interaction in the late Archaean evolution of Karnataka craton, southern India. Precambrian Research, 16: 31-54. doi:10.1016/0301-9268(81)90004-8.

Chadwick, B., Vasudeva, V., and Swaminathan, J. 1988. Statigraphy and structure of late Archaean Dharwar volcanic and sedimentary rocks and their basements in a part of the Shimoga basin east of Badravathi, Karnataka. Journal of Geological Society of India, 32: 1-19.

Chadwick, B., Vasudev, V.N., and Ahmed, N. 1996. The Sandur schist belt and its adjacent plutonic rocks. Journal of the Geological Society of India, 47:37-57.

Chadwick, B., Vasudev, V.N., and Hegde, G.V. 2000. The Dharwar craton, southern India, interpreted as the result of Late Archaean oblique convergence. Precambrian Research, 99: 91-111. doi:10.1016/S0301-9268(99)00055-8.

Chardon, D., Choukroune, P., and Jayananda, M. 1998. Sinking of the Dharwar 
basin (South India): implications for Archaean tectonics. Precambrian Research, 91: 15-39. doi:10.1016/S0301-9268(98)00037-0.

Chardon, D., Jayananda, M., Chetty, T.R.K., and Peucat, J.-J. 2008. Precambrian Continental strain and shear zone patterns: the South Indian case. Journal of Geophysical Research, 113: B08402. doi:10.1029/2007JB005299.

Cheney, E.S. 1996. Sequence stratigraphy and plate tectonic significance of the Transvaal succession of southern Africa and its equivalent in Western Australia. Precambrian Research, 79: 3-24. doi:10.1016/0301-9268(95)00085-2.

Condie, K.C. 2004a. Precambrian superplume events. In The Precambrian Earth: Tempos and Events. Edited by P.G. Eriksson, W. Altermann, D.R. Nelson, W.U. Mueller, and O. Catuneanu. Developments in Precambrian Geology Vol. 12. Elsevier, Amsterdam. pp. 163-173.

Condie, K.C. 2004b. Supercontinents and superplume events: distinguishing signals in the geological record. Physics of the Earth and Planetary Interiors, 146: 319-332. doi:10.1016/j.pepi.2003.04.002.

Condie, K.C., Des Marais, D.J., and Abbott, D. 2001. Precambrian superplumes and supercontinents: a record in black shales, carbon isotopes and paleoclimates. Precambrian Research, 106: 239-260. doi:10.1016/S0301-9268(00)00097-8.

Crawford, A.R. 1969. Reconnaissance Rb-Sr dating of the Precambrian rocks of southern Peninsular India. Journal of the Geological Society of India, 10: 117-187.

Dalziel, I.W.D. 1991. Pacific margins of Laurentia and east Antarctica-Australia as a conjugate rift pair: evidence and implications for an Eocambrian supercontinent. Geology, 19: 598-601. doi:10.1130/0091-7613(1991)019<0598: PMOLAE $>2.3 . C O ; 2$.

Dalziel, I.W.D. 1997. Overview: Neoproterozoic-Palaeozoic geography and tectonics: review, hypothesis, environmental speculations. Geological Society of America Bulletin, 109: 16-42. doi:10.1130/0016-7606(1997)109<0016:ONPGAT>2.3. $\mathrm{CO} ; 2$.

De Kock, M.O., Evans, D.A.D., and Beukes, N.J. 2009. Validating the existence of Vaalbara in the Neoarchean. Precambrian Research, 174: 145-154. doi:10.1016/ j.precamres.2009.07.002.

de Wit, M.J., and Ashwal, L.D. 1997. Greenstone Belts. Oxford Monographs on Geology and Geophysics, No 35, Oxford University Press, Oxford.

de Wit, M.J., Roering, C., Hart, R.J., Armstrong, R.A., de Ronde, C.E.J., Green, R.W.E., Tredoux, M., Peberdy, E., and Hart, R.A. 1992. Formation of an Archaean continent. Nature, 357: 553-562. doi:10.1038/357553a0.

Dey, S. 2013. Evolution of Archaean crust in the Dharwar craton: The Nd isotope record. Precambrian Research, 227: 227-246. doi:10.1016/j.precamres.2012.05. 005 .

Divakar Rao, V., and Rama Rao, P. 1982. Granitic activity and crustal growth in the Indian Sheild. Precambrian Research, 16: 257-271. doi:10.1016/03019268(82)90063-8.

Drury, S.A, Naqvi, S.M, and Hussain, S.M. 1978. Ree Distributions in Basaltic Anorthosites from the Holenarasipur Greenstone Belt, Karnataka, South India. In: B.F. Windley and S.M. Naqvi, Editor(s), Developments in Precambrian Geology, Elsevier, Volume1, pp. 363-374. doi:10.1016/S0166-2635(08)70107-5.

Drury, S.A.H., Holt, R.W., Reeves-Smith, G.J., and Wightman, R.T. 1984. Precambrian tectonics and Crustal evolution in South India. Journal of Geology, 92: 3-20. doi:10.1086/628831.

Eglington, B.M., and Armstrong, R.A. 2004. The Kaapvaal Craton and adjacent orogens, southern Africa: a geochronological database and overview of the geological development of the craton. South African Journal of Geology, 107: 13-32. doi:10.2113/107.1-2.13.

Eriksson, P.G., and Condie, K.C. 2013. Cratonic sedimentation regimes in the ca. 2450 - 2000 Ma period: relationship to a possible widespread magmatic slowdown on Earth? Gondwana Research, 25(1): 30-47. doi:10.1016/j.gr.2012. 08.005 .

Eriksson, P.G., Mazumder, R., Sarkar, S., Bose, P.K., Altermann, W., and van der Merwe, R. 1999. The 2.7-2.0 Ga volcano-sedimentary record of Africa, India and Australia: evidence for global and local changes in sea level and continental freeboard. Precambrian Research, 97: 269-302. doi:10.1016/S03019268(99)00035-2.

Eriksson, P.G., Condie, K.C., van der Westhuizen, W.A., van der Merwe, R., de Bruiyn, H., Nelson, D.R., Altermann, W., and Cunningham, M.J. 2002. Late Archaean superplume events: A Kaapvaal-Pilbara perspective. Journal of Geodynamics, 34: 207-247. doi:10.1016/S0264-3707(02)00022-4.

Eriksson, P.G., Catuneanu, O., Nelson, D.R., Mueller, W.U., and Altermann, W. 2004. Towards a synthesis. In The Precambrian Earth: Tempos and Events. Edited by P.G. Eriksson, W. Altermann, D.R. Nelson, W.U. Mueller, and O. Catuneanu. Developments in Precambrian Geology Vol. 12. Elsevier, Amsterdam. pp. 739-769.

Eriksson, P.G., Mazumder, R., Catuneanu, O., Bumby, A.J., and Ountsche' Ilondo, B. 2006a. Precambrian continental freeboard and geological evolution: A time perspective. Earth-Science Reviews, 79: 165-204. doi: 10.1016/j.earscirev.2006.07.001.

Eriksson, P.G., Altermann, W., and Hartzer, F.J. 2006b. The Transvaal Supergroup and its precursors. In The Geology of South Africa. Edited by M.R. Johnson, C.R. Anhaeusser, and R.J. Thomas. R.J. Geological Society of South Africa and Pretoria, Council for Geoscience, Johannesburg. pp. 237-260.

Eriksson, P.G., Banerjee, S., Nelson, D.R., Rigby, M.J., Catuneanu, O., Sarkar, S., Roberts, R.J., Ruban, D., Mtimkulu, M.N., and Sunder Raju, P.V. 2009. A Kaapvaal craton debate: nucleus of an early small supercontinent or affected by an enhanced accretion event? Gondwana Research, 15: 354-372. doi:10. 1016/j.gr.2008.08.001.

Eriksson, P.G., Lenhardt, N., Wright, D.T., Mazumder, R, and Bumby, A.J. $2011 a$. Late Neoarchaean-Palaeoproterozoic supracrustal basin-fills of the Kaapvaal craton: Relevance of the supercontinent cycle, the "Great Oxidation Event" and "Snowball Earth"? Marine and Petroleum Geology, 28: 1385-1401. doi:10. 1016/j.marpetgeo.2011.05.007.

Eriksson, P.G., Rigby, M.J., Bandopadhyay, P.C., and Steenkamp, N.C. 2011b. The Kaapvaal Craton, South Africa: no evidence for a supercontinental affinity prior to $2.0 \mathrm{Ga}$ ? International Geology Review, 53: 1312-1330. doi:10.1080/ 00206814.2010.527638.

Ernst, R.E., Buchan, K.L., and Campbell, I.H. 2005. Frontiers in Large Igneous Province research. Lithos, 79: 271-297. doi:10.1016/j.lithos.2004.09.004.

Foote, R.B. 1886. Notes on the geology of parts of Bellary and Ananthapur districts. Records of Geological Survey of India, 19: 97-111.

Frimmel, H.E. 2005. Archaean atmospheric evolution: evidence from the Witwatersrand gold fields, South Africa. Earth-Science Reviews, 70: 1-46. doi:10. 1016/j.earscirev.2004.10.003.

Gaál, G. 1992. Global Proterozoic tectonic cycles and Early Proterozoic metallogeny. South African Journal of Geology, 95: 79-87.

Geological Survey of India Miscellaneous publication. 2006. Geology and Mineral resources of the states of India, Part VII- Karnataka and Goa. 51 p.

Ghosh, S.K., and Sengupta, S. 1985. Superposed folding and shearing in western quartzite of Kolar Gold Field. Indian Journal of Earth Sciences, 12: 1-8.

Glikson, A.Y. 1979. Early Precambrian tonalite-trondhjemite sialic nucleii. EarthScience Reviews, 15: 1-73. doi:10.1016/0012-8252(79)90043-6.

Gnaneswar Rao, T., and Naqvi, S.M. 1995. Geochemistry, depositional environment and tectonic setting of the BIF of late Archean Chitradurga schist belt, India. Chemical Geology, 121: 217-243. doi:10.1016/0009-2541(94)00116-P.

Hartnady, C.J.H. 1986. Was North America (Laurentia) part of southwestern Gondwanaland during the Late Proterozoic Era. South African Journal of Earth Sciences, 82: 251-254.

Hoffman, P.F. 1991. Did the breakout of Laurentia turn Gondwanaland inside out? Science, 252: 1409-1412. doi:10.1126/science.252.5011.1409. PMID:17772912.

Hokada, T., Horie, K., Satish-Kumar, M., Ueno, Y., Nasheeth, A., Mishima, K., and Shiraishi, K. 2013. An appraisal of Archaean supracrustal sequences in Chitradurga Schist Belt, Western Dharwar Craton, Southern India. Precambrian Research, 227: 99-119. doi:10.1016/j.precamres.2012.04.006.

Hou, G., Santosh, M., Qian, X., Lister, G.S., and Li, J. 2008. Configuration of the Late Paleoproterozoic Supercontinent Columbia: Insights from radiating Mafic Dyke Swarms. Gondwana Research, 14: 395-409. doi:10.1016/j.gr.2008.01.010.

Hussain, S.M., and Naqvi, S.M. 1983. Geological, geophysical and geochemical studies over the Holenarasipur schist belt, Dharwar craton, India. Memoir of the Geological Society of India, 4:73-95.

Janardhan, A.S., and Srikantappa, C. 1975. Geology of the northern parts of the Sargur schist belt between Mavinahalli and Dod kyana, Mysore district, Karnataka. Indian Mineralogist, 16: 66-75.

Janardhan, A.S., Swamy, N.S., and Capdevila, R. 1986. Banded iron formation and associated manganiferous horizon of the Sargur supra crustals Southern Karnataka. Journal of Geological Society of India, 28: 179-188.

Jayananda, M., Moyen, J.-F., Martin, H., Peucat, J.-J., Auvray, B., and Mahabaleswar, B. 2000. Late Archaean (2550-2520 Ma) juvenile magmatism in the eastern Dharwar craton, southern India: constraints from geochronology, $\mathrm{Nd}-\mathrm{Sr}$ isotopes and whole rock geochemistry. Precambrian Research, 99: 225-254. doi:10.1016/S0301-9268(99)00063-7.

Jayananda, M., Peucat, J.-J., Chardon, D., Krishna Rao, B., Fanning, C.M., and Corfu, F. 2013. Neoarchean greenstone volcanism and continental growth, Dharwar craton, southern India: Constraints from SIMS U-Pb zircon geochronology and Nd isotopes. Precambrian Research, 227: 55-76. doi:10.1016/ j.precamres.2012.05.002.

Kumar, A., Hamilton, M.A., and Halls, H.C. 2012. A Paleoproterozoic giant radiating dyke swarm in the Dharwar Craton, southern India. Geochemistry, Geophysics, Geosystems, 13: Q02011. doi:10.1029/2011GC003926.

Manikyamba, C., Balaram, V., and Naqvi, S.M. 1993. Geochemical signatures of polygenetic BIF of Archean Sandur greenstone belt (schist belt), Karnataka Nucleus, India. Precambrian Research, 72: 69-95.

Mazumder, R., Eriksson, P.G., De, S., Bumby, A.J., and Lenhardt, N. 2012. Palaeoproterozoic sedimentation on the Singhbhum Craton: global context and comparison with Kaapvaal. In Palaeoproterozoic of India. Edited by R. Mazumder and D. Saha. Geological Society of London of Special Publication, 365: 51-76.

Meert, J.G. 2002. Paleomagnetic evidence for a Paleo-Mesoproterozoic supercontinent. Gondwana Research, 5: 207-215. doi:10.1016/S1342-937X(05)70904-7.

Meert, J.G., Pandit, M.K., Pradhan, V.R., Banks, J., Sirianni, R., Stroud, M., Newstead, B., and Gifford, J. 2010. Precambrian crustal evolution of Peninsular India: A 3.0 billion year odyssey. Journal of Asian Earth Sciences, 39: 483-515. doi:10.1016/j.jseaes.2010.04.026.

Miall, A.D. 1997. The Geology of Stratigraphic Sequences. Springer-Verlag, Berlin.

Mohan, M.R., Satyanarayanan, M., Santosh, M., Sylvester, P.J., Tubrett, M., and Lam, R. 2013. Neoarchean suprasubduction zone arc magmatism in southern India: Geochemistry, zircon U-Pb geochronology and $\mathrm{Hf}$ isotopes of the Sittampundi Anorthosite Complex. Gondwana Research, 23: 539-557. doi:10. 1016/j.gr.2012.04.004.

Monrad, J.R. 1983. Evolution of sialic terranes in the vicinity of Holenarasipur 
belt, Hassan district, Karnataka, India. Memoir of the Geological Society of India, 4: 343-365.

Moores, E.M. 1991. Southwest U.S.-East Antarctic (SWEAT) connection: a hypothesis. Geology, 19: 425-428. doi:10.1130/0091-7613(1991)019<0425:SUSEAS>2.3. $\mathrm{CO} ; 2$.

Mukhopadhyay, D. 1986. Structural pattern in the Dharwar craton. Journal of Geology, 94: 167-186. doi:10.1086/629021.

Naha, K., Srinivasan, R., and Naqvi, S.M. 1986 Structural unity in the Early Precambrian Dharwar tectonic province, Peninsular India. Quatarly Journal of the Geological Mining and Metallurgical Society of India, 58: 219-243.

Naha, K., Srinivasan, R., and Jayaram, S. 1990. Structural evolution of the Peninsular Gneiss - an Early Precambrian migmatitic complex from South India. Geologische Rundschau, 79: 99-109. doi:10.1007/BF01830449.

Naha, K., Srinivasan, R., and Jayaram, S. 1991. Sedimentological, structural and migmatitic history of the Archaean Dharwar tectonic province, southern India. Proceedings of the Indian Academy of Science (Earth Planetary Science), 100: 413-433.

Naqvi, S.M. 1973. Geological structure and aeromagnetic and gravity anomalies in the central part of the Chitaldrug Schist belt, Mysore, India. Geological Society of America Bulletin, 84: 1721-1732. doi:10.1130/0016-7606(1973)84<1721:GSAAAG> 2.0.CO;2.

Naqvi, S.M. 1978. Geochemistry of Archaean Metasediments; Evidence for Prominent Anorthosite-Norite-Troctolite (ANT) in the Archaean Basaltic Primordial Crust. In: B.F. Windley and S.M. Naqvi, Editor(s), Developments in Precambrian Geology, Elsevier, Volume 1, pp. 343-360. doi:10.1016/S01662635(08)70106-3.

Naqvi, S.M. 1981. The oldest supracrustals of the Dharwar Craton. Journal of Geological Society of India, 22: 458-469.

Naqvi, S.M. 1985. Chitradurga Schist Belt- An Archaean suture (?). Journal of Geological Society of India, 26: 511-525.

Naqvi, S.M., and Hussain, S.M. 1973. Geochemistry of Dharwar metavolcanics and the composition of the primeval crust of Peninsular India. Geochimica et Cosmochimica Acta, 37: 159-164. doi:10.1016/0016-7037(73)90254-8.

Naqvi, S.M., and Rogers, J.J.W. (Eds.) 1983. Precambrian of South India. Memoir of the Geological Society of India, 4: 1-575.

Naqvi, S.M., and Rogers, J.J.W. 1987. Precambrian Geology of India. Oxford Monographs on Geology and Geophysics, Vol. 6. Oxford University Press, Oxford.

Naqvi, S.M., Divakar Rao, V., and Narain, H. 1974. The Protocontinental growth of the Indian Sheild and antiquity o fits rift valleys. Precambrian Research, 1 : 345-398. doi:10.1016/0301-9268(74)90005-9.

Naqvi, S.M., Hanumantha Rao, T., Natarajan, R., Satyanaryana, K., Divakara Rao, V., and Hussain, S.M. 1977. Mineralogy, geochemistry and genesis of massive basemetal sulphide depoits of Chitradurga (Ingaldahl), Karnataka, India. Precambrian Research, 4: 361-386. doi:10.1016/0301-9268(77)90004-3.

Naqvi, S.M., Narayan, B.L., Rama Rao, R., Ahmad, S.M., and Udai Raj, B. 1980. Geology and geochemistry of the paragneisses from Jawanahalli schist belt, Karnataka, India. Journal of the Geological Society of India, 21: 577-592.

Naqvi, S.M., Sawkar, R.H., Subbarao, D.V., Govil, P.K., and Gnaneswar Rao, T. 1988. Geology, geochemistry and tectonic setting of Archean greywackes from Karnataka nucleus. Precambrian Research, 39: 193-216. doi:10.1016/ 0301-9268(88)90042-3.

Narayana, B.L., Naqvi, S.M., Rama Rao, P., Udai Raj, B., and Ahmad, S.M. 1983. Geology and geochemistry of Javanahalli schist belt, Karnataka, India. Memoir of the Geological Society of India, 4: 143-157.

Nelson, D.R. 2008. Geochronology of the Archean of Australia. Australian Journal of Earth Sciences, 55: 1-15. doi:10.1080/08120090701673310.

Personen, L.J., Elming, S.-A., Mertanen, S., Pisarevsky, S., D’Agrella-Filho, M.S., Meert, J.G., Schmidt, P.W., Abrahamsen, N., and Bylund, G. 2003. Palaeomagnetic configuration of continents during the Proterozoic. Tectonophysics, 375: 289-324. doi:10.1016/S0040-1951(03)00343-3.

Peucat, J.J., Mahabaleswar, B., and Jayananda, M. 1993. Age of younger tonalitic magmatism and granulitic metamorphism in the South Indian transition zone (Krishnagiri area): comparison with older Peninsular gneisses from the Gorur-Hassan area. Journal of Metamorphic Geology, 11: 879-888. doi:10.1111/ j.1525-1314.1993.tb00197.x.

Peucat, J.-J., Jayananda, M., Chardon, D., Capdevila, R., Fanning, C.M., and Paquette, J.-L. 2013. The lower crust of the Dharwar Craton, south India: patchwork of Archean granulitic domains. Precambrian Research, 227: 4-28. doi:10.1016/j.precamres.2012.06.009.

Pichamuthu, C.S., and Srinivasan, R. 1984. The Dharwar Craton. Perspective Report Series 7, Indian National Science Academy, New Delhi.

Piper, J.D.A. 1983. Proterozoic palaeomagnetism and single continent plate tectonics. Geophysical Journal of the Royal Astronomical Society, 74: 163-197.

Radhakrishna, B.P. 1967. Copper in Mysore State. Mysore Department of Mines and Geology.

Radhakrishna, B.P. 1983. Archaean granite-greenstone terrane of South India Sheild. Memoir of the Geological Society of India, 4: 1-46.

Radhakrishna, B.P. 1984. Crustal evolution and Metallogeny- Evidence from the Indian Shield. Journal of Geological Society of India, 25: 617-640.

Radhakrishna, B.P., and Naqvi, S.M. 1986. Precambrian continental crust of India and its evolution. Journal of Geology, 94: 145-166. doi:10.1086/629020.
Radhakrishna, B.P., and Ramakrishnan, M. 1990. Archaean greenstone belts of south India. Memoir of the Geological Society of India, 19: 1-497.

Raju, P.V.S. 2009. Petrography and geochemical behaviour of trace element, REE and precious metal signatures of sulphidic banded iron formations from the Chikkasiddavanahalli area, Chitradurga Schist Belt, India. Journal of Asian Earth Sciences, 34: 663-673. doi:10.1016/j.jseaes.2008.10.005.

Ramakrishnan, M. 1980. Geology of the Javanahalli, Holenarsipur and Sargur schist belts of Karnataka craton and the geochemistry of mafic rocks. Ph.D thesis, Indian Institute of Science, Bangalore.

Ramakrishnan, M.S., and Swaminatha, J. 1976. Dharwar stratigraphic model and Karnataka tectonic evolution. Records of Geological Survey of India, 107: 149-175.

Ramakrishnan, M., and Vaidyanadhan, R. 2008. Geology of India. Vol. 1, Geological Society of India, Bangalore.

Ramakrishnan, M., and Viswanatha, M.N. 1981. Chitradurga belt; Geological Survey of India Memoir, 112: 115-142.

Rogers, J.J.W. 1986. Dharwar craton and the assembly of peninsular India. Journal of Geology, 94: 129-143. doi:10.1086/629019.

Rogers, J.J.W. 1996. A history of continents in the past three billion years. Journal of Geology, 104: 91-107. doi:10.1086/629803.

Rogers, J.J.W., and Santosh, M. 2002. Configuration of Columbia, a Mesoproterozoic supercontinent. Gondwana Research, 5: 5-22. doi:10.1016/S1342-937X (05)70883-2.

Roy, A., and Biswas, S.K. 1979. Metamorphic history of the Sandur Schist Belt, Karnataka. Journal of Geological Society of India, 20: 179-187.

Sarma, D.S., Mc Naughton, N.J., Belousova, E., Ram Mohan, M., and Fletcher, I.R. 2012. Detrital zircon U-Pb ages and Hf-isotope systematic from the Gadag Greenstone Belt: Archean crustal growth in the western Dharwar Craton, India. Gondwana Research, 22: 843-854. doi:10.1016/j.gr.2012.04.001.

Smirnov, A.V., Evans, D.A.D., Ernst, R.E., Söderlund, U., and Li, Z-X . 2013. Trading partners: Tectonic ancestry of southern Africa and western Australia, in Archean supercratons Vaalbara and Zimgarn. Precambrian Research, 224: 11-22. doi:10.1016/j.precamres.2012.09.020.

Srinivasan, R., and Sreenivas, B.L. 1972. Dharwar stratigraphy. Journal of the Geological Society of India, 13: 75-85.

Stanistreet, I.G. 1993. Ancient and modern examples of tectonic escape basins: the Archaean Witwatersrand Basin compared with the Cenozoic Maracaibo Basin. In Tectonic Controls and Signatures in Sedimentary Successions. Edited by L.E. Frostick and R.J. Steel. International Association of Sedimentologists Special Publications, Vol. 20. Blackwell, Oxford. pp. 363-376.

Strik, G., de Wit., M.J., and Langereis, C.G. 2007. Palaeomagnetism of the Neoarchaean Pongola and Ventersdorp Supergroups and an appraisal of the 3.0-1.9 $\mathrm{Ga}$ apparent polar wander path of the Kaapvaal Craton, Southern Africa. Precambrian Research, 153: 96-115. doi:10.1016/j.precamres.2006.11.006.

Swami Nath, J., and Ramakrishnan, M. 1981. Early Precambrian supracrustals of Southern Karnataka. Memoir of the Geological Survey of India, 112: 23-38.

Swami Nath, J., Ramakrishnan, M., and Viswanatha, M.N. 1976. Dharwar stratigraphic model and Karnataka craton evolution. Records of the Geological Survey of India, 107: 149-175.

Taylor, P.N., Chadwick, B., Moorbath, S., Ramakrishnan, M., and Viswanatha, M.N. 1984. Petrography, Chemistry and isotopic ages of peninsular gneisses, Dharwar acid volcanic rocks and the Chitradurga granite with special reference to the late Archaean evolution of the Karnataka craton. Precambrian Research, 23: 349-375. doi:10.1016/0301-9268(84)90050-0.

Unrug, R. 1992. Supercontinent cycle and Gondwana assembly: component cratons and timing of suturing events. Journal of Geodynamics, 16(4): 215-240. doi:10.1016/0264-3707(92)90011-G.

Venkatasubramanian, V.S., and Narayanaswamy, R. 1974 Ages of gneissic pebbles in Kaldurga conglomerates. Journal of the Geological Society of India, 15: 318-319.

Viswanatha, M.N., and Ramakrishnan, M. 1976. The pre-Dharwar supracrustal rocks of Sargur Schist Complex in southern Karnataka and their tectonometamorphic significance. Indian Mineralogist, 16: 48-65.

Viswanatha, M.N., and Ramakrishnan, M. 1981. Bababudan belt in early Precambrian supracrustal of Southern Karnataka. Journal of the Geological Society of India, 26: 580-598.

Williams, H., Hoffman, P.F., Lewry, J.F., Monger, J.W.H., and Rivers, T. 1991. Anatomy of North America: thematic portrayals of the continent. Tectonophysics, 187: 117-134. doi:10.1016/0040-1951(91)90416-P.

Wilson, J.T. 1965. A new Class of Faults and their Bearing on Continental Drift. Nature, 207: 343-347. doi:10.1038/207343a0.

Wilson, J.T. 1966. Did the Atlantic close and then re-open? Nature, 211: 676-681. doi:10.1038/211676a0.

Wingate, M.T.D. 1998. A palaeomagnetic test of the Kaapvaal-Pilbara (Vaalbara) connection at $2.78 \mathrm{Ga}$ : South African Journal of Geology, 101: 257-274.

Zeh, A., Gerdes, A., and Barton, J.M., Jr. 2009. Archean accretion and crustal evolution of the Kalahari Craton - the zircon age and Hf isotope record of granitic rocks from Barberton/Swaziland to the Francistown Arca. Journal of Petrology, 50: 933-966. doi:10.1093/petrology/egp027.

Zhong, S., Zhang, N., Li, Z.-X., and Roberts, J.H. 2007. Supercontinent cycles, true polar wander, and very long-wave length mantle convection. Earth and Planetary Science Letters, 261: 551-564. doi:10.1016/j.eps1.2007.07.049. 